\title{
Getting Leopards to Change Their Spots Co-creating a New Professional Role Identity
}

\author{
Reay, Trish; Goodrick, Elizabeth; Waldorff, Susanne Boch; Casebeer, Ann
}

Document Version

Accepted author manuscript

Published in:

Academy of Management Journal

DOI:

10.5465/amj.2014.0802

Publication date:

2017

License

Unspecified

Citation for published version (APA):

Reay, T., Goodrick, E., Waldorff, S. B., \& Casebeer, A. (2017). Getting Leopards to Change Their Spots: Cocreating a New Professional Role Identity. Academy of Management Journal, 60(3), 1043-1070.

https://doi.org/10.5465/amj.2014.0802

Link to publication in CBS Research Portal

\section{General rights}

Copyright and moral rights for the publications made accessible in the public portal are retained by the authors and/or other copyright owners and it is a condition of accessing publications that users recognise and abide by the legal requirements associated with these rights.

Take down policy

If you believe that this document breaches copyright please contact us (research.lib@cbs.dk) providing details, and we will remove access to the work immediately and investigate your claim. 


\section{Getting Leopards to Change Their Spots: Co-creating a New Professional Role Identity}

\section{Trish Reay, Elizabeth Goodric, Susanne Boch Waldorff, and Ann Casebeer}

Journal article (Accepted version)

CITE: Getting Leopards to Change Their Spots: Co-creating a New Professional Role Identity. / Reay, Trish; Goodrick, Elizabeth; Waldorff, Susanne Boch; Casebeer, Ann. In: Academy of Management Journal, Vol. 60, №. 3, 2017, p. 1043-1070.

DOI: 10.5465/amj.2014.0802

Uploaded to Research@CBS: February २०18 


\title{
GETTING LEOPARDS TO CHANGE THEIR SPOTS: CO-CREATING A NEW PROFESSIONAL ROLE IDENTITY
}

\begin{abstract}
We investigated how professional role identity change can be accomplished in highly institutionalized contexts characterized by resiliency. We show that the collective professional role identity of family physicians was changed through a process of reinterpreting multiple logics and their relationships. Through our inductive analyses, we identified four mechanisms that occurred through social interactions and collectively served to rearrange the constellation of logics guiding physician role identity: (1) revealing the influence of a hidden logic, (2) reinforcing the conflict between logics, (3) reframing the meaning of a dominant logic, and (4) re-embedding the new arrangement of logics. We found that the change in physician professional role identity required significant identity work by a group of actors, but particularly by the managers who had been charged with leading the reform initiative. We contribute to the professional role identity and institutional literatures by showing how others can engage in social interactions with professionals to facilitate the reinterpretation and rearranging of institutional logics that guide collective professional role identity.
\end{abstract}

Key words: Professional role identity; Institutional logics; Social interactions

\section{INTRODUCTION}

Family doctors are the last bastion of "I'm going to run my own shop and do it my way" and "I've been expected all along to do everything so that's what I've done and I'm not about to change just because you say some nurse is going to come in here and do some work for me now. (Physician interviewed before change initiative)

Yes, absolutely it's different [than before]. Physicians are still the key decision-maker, but involving other healthcare professionals. And I think it's almost like a family. You want to know who's in charge of the family. And make sure that there is one person ultimately that becomes kind of like the person to go to - we are that person. (Physician interviewed at end of our study)

The above quotes illustrate how family physicians (called general practitioners or GPs in many countries) viewed themselves at the beginning of our study (T0) compared to the end (T3). It is notable that before the implementation of a Canadian government-designed initiative to reform primary health care and family physicians' role, physicians saw themselves as independent, autonomous professionals who treated patients one-by-one in their offices with little, if any, help from anyone else. The heart of the reform initiative was to create multi- 
disciplinary teams of health professionals that included physicians, thereby improving patient care and reducing health system costs. Initially, there was a small group of 'renegade' physicians who visualized a new role identity; however, the majority of physicians were skeptical or disinterested in change. Over the three years of our study, we heard from interviewees how managers became involved in the change initiative, and facilitated (together with renegade physicians and other professionals) the development of a new professional role identity (how they saw themselves and the work that they did) for physicians at the collective level. By the end of our study, physicians saw themselves as expert professionals who relied on a team of other health professionals to provide an array of services for patients. This change is significant in a highly institutionalized context such as health care, because in such settings, the taken-forgranted norms, values and beliefs about how things are done mean that role identities are highly resilient - they are sustained by common understandings about who does what, under what circumstances and therefore how each actor group view themselves and each other (Scott, 2014). Our research puzzle was to understand how such a change in professional role identity occurred.

Professionals hold significant roles in today's society. For much of history they have controlled their own destiny, but more recent changes such as government reforms, marketization or internationalization of services have resulted in situations where external pressure can be exerted on professionals to significantly alter their work practices and thus their professional role identity. Therefore, not only for our research puzzle, but also much more broadly, it is critical to understand the dynamics through which professional role identity can change. Professional role identity refers to how professionals define themselves in terms of the work that they do (Chreim, Williams, \& Hinings, 2007; Pratt, Rockmann \& Kaufmann, 2006); it is inherently relational since roles are defined and enacted in relationship to others (Stryker, 
2007; Vough, Bednar, Cardador, Dane, \& Pratt, 2013). Since professional work role and professional identity are so tightly bound together, changing professional role identity is particularly difficult in highly institutionalized contexts with established practices and routines that rely on mutual role expectations and interactions with multiple other actors (Edmondson, Bohmer \& Pisano, 2001; Currie, Lockett, Finn, Martin \& Waring, 2012).

The literature to date has focused on particular aspects of professional role identity. Scholars have shown how new professionals take on an established professional role identity as part of a desired career transition (e.g. Becker, Geer, Hughes, \& Strauss, 1961; Ibarra, 1999; Pratt et al., 2006), how professionals take on a new role identity with the creation of a new specialty (Reay, Golden-Biddle, \& GermAnn, 2006; Pouthier, Steele, \& Ocasio, 2013), and how a few self-motivated professionals can develop a new role identity in contrast to their colleagues (Chreim et al., 2007). However, there has been very little attention to how professional role identity at the collective level can be changed, especially when many professionals are themselves skeptical about the value of such change.

We examine a process of collective professional role identity change in our study of primary health care reform in a Western Canadian province. While studies show that initiatives to change physicians' views are seldom successful (Currie et al., 2012; Reay \& Hinings, 2005), our case is one where change was realized. Physician role identities are incredibly resilient because they are highly socialized and institutionalized (Becker et al., 1961; Scott, 2008). This resiliency resembles the biblical story of Jeremiah who after unsuccessfully attempting to persuade an evil shepherdess to become good, said, "Can the leopard change its spots?" - thus insinuating that such change was virtually impossible. Similar to the extraordinarily difficult challenge of getting leopards to change their spots, the highly institutionalized setting in our case 
provides an excellent opportunity to understand how changes in collective professional role identity can be facilitated when there are many forces for resiliency.

We draw on institutional theory, specifically the concept of institutional logics, to understand how professional role identity can change within a highly resilient institutional context. Institutional logics are the organizing principles that guide individuals and organizations; they are also available for actors to draw upon and thus recursively connect with behavior and the dynamics of identity (Friedland \& Alford, 1991; Thornton, Ocasio, \& Lounsbury, 2012). Recent work characterizing organizational fields as guided by a constellation of logics rather than a single logic has opened up opportunities for exploring a more agentic approach in which logics and their relationships are interpreted by social actors (Goodrick \& Reay, 2011; Greenwood, Raynard, Kodeih, Micelotta, \& Lounsbury, 2011). While this emerging approach has produced nuanced accounts of how social actors achieve desired goals (e.g., Currie \& Spyridonidis, 2015; McPherson \& Saunder, 2013; Smets, Jarzabkowski, Burke, \& Spee, 2015), there has not yet been consideration of how identity change can occur in association with the guiding constellation of institutional logics.

Consequently, our research was guided by the following question: How can social actors facilitate changes in collective professional role identity by reinterpreting institutional logics and their relationships? We contribute to theory by drawing on literature regarding the relationships among multiple co-existing institutional logics and previous conceptualizations about the importance of social interactions and relational spaces. We show that in highly institutionalized contexts, although change is exceptionally difficult, professional role identity can be altered through the collective efforts of others (together with professionals) to reinterpret and rearrange the guiding constellation of logics. Second, we show that different types of relational spaces can 
facilitate the social interactions through which institutional logics are rearranged. And third, we add to the literature on institutional logics by showing the existence and importance of logics hidden within a constellation and providing explanations of change that highlight actors' interpretations and the underlying meaning of combinations of logics.

\section{Professional Role Identity and Change}

Professional role identity refers to the way that professionals see themselves in terms of who they are and what they do (Chreim et al., 2007; Goodrick \& Reay, 2010; Nelson \& Irwin, 2014; Pratt et al., 2006). As Barley pointed out, 'role' and 'identity' are two sides of the same coin--- role looks outward "toward a pattern of situated activity, whereas identity look(s) inward toward the actor's subjective experience of that situated being" (1989:50). Thus, roles and role enactment are central to identity (Stryker \& Serpe, 1982). The connection between role and identity is particularly strong for professionals; when asked to explain how they see themselves,

they commonly respond with statements about the work that they do (Pratt et al., 2006). Through lengthy educational and socialization processes, professionals develop intense connections to their work and come to define themselves with respect to the goals, values, norms, and interaction patterns associated with their work, often in contrast to the work of others (Abbott, 1988; Becker, et al., 1961; Freidson, 2001).

Professional role identity has been considered at both the individual and collective level (Chreim et al., 2007; Sluss \& Ashforth, 2007). At the individual level, researchers have theorized how individual professionals develop their own professional role identity through educational or training processes (e.g., Ibarra, 1999; Pratt et al., 2006). This process of change is one where individuals take on the established role identity of a group or collective. Other researchers have focused on change in professional role identity at the collective level. For example, Goodrick and 
Reay (2010) investigated how registered nurses in the US developed and legitimized a new professional role identity at the collective level. Somewhat similarly, Nelson and Irwin (2014) examined how librarians redefined their collective role identity in response to technology changes that threatened their existence.

Rather than reflecting the aggregate or average of all professionals' identities, collective professional role identity represents the predominant way in which professionals understand who they are in relationship to others and the work they do (Powell \& DiMaggio, 1991; Pouthier et al., 2013). Consequently, even in the same institutional context, there is typically some variation in how individuals define themselves in terms of their work. Pouthier et al. (2013) described how some hospitalist physicians disassociated themselves from the tenets of managed care, which had historically been part of the collective identity of hospitalists. Barbour and Lammers (2015) found variation among physicians across organizations in certain aspects of professional identity while there was little or no variation on other aspects. As Pouthier et al. (2013) document, this variation can lead to change that is eventually reflected in a new collective role identity.

Professional role identities are relational and thus embedded in interactions (Stryker, 2007; Vough et al., 2013). Roles, and consequently role identities, are defined in relationship to others; role occupants enact their respective roles vis-a-vis one another (Sluss \& Alforth, 2007). Professionals or other role occupants define their own role identity by reciprocally situating themselves in relation to others through ongoing interaction (Langely et al., 2013; Sluss \& Ashforth, 2007). As Edmondson et al. (2001) illustrated in their study of the implementation of a new surgical technique, the development of a new role for the surgical team required interaction among all professionals in an interdependent system. Similarly, Reay et al. (2006) showed that the development of a new role for nurse practitioners required ongoing interactions with other 
health care providers. As Stryker and Statham conclude, "To use the term role is to necessarily refer to interaction" (1985: 323).

Existing studies of professional role identity are based on the assumption that roles are relational; however the importance of interactions between professionals and others has been relegated to the background. For example, Pratt et al. (2006) showed how feedback from senior physicians, nurses and even patients contributed to the development of physician professional identity, but their focus was on explicating the relationship between the work resident physicians did and how they saw themselves. Somewhat similarly, Pouthier et al. (2013) showed how the role identity of hospitalists was challenged by the negative opinions of other key stakeholders in the health care field, but they focused on the physicians themselves. And Chreim et al. (2007) pointed to the impact of a new team structure where actors held different perspectives; however, their attention was on how physicians themselves reconstructed their own role identity.

Some scholars describe active efforts to modify or sustain identity as 'identity work'. Primarily focusing on individuals (Brown, 2015; Brown \& Lewis, 2011), research on identity work provides insights into the range of activities to create, maintain, repair, or revise identity (Snow \& Anderson, 1987; Sveningsson \& Alvesson, 2003). Although most studies suggest that individuals conduct their own identity work, some researchers have shown ways that actors influence another's identity through processes of identity regulation (Alvesson \& Willmott, 2002) or identity conditioning (Lok, 2010). However, only a few studies have investigated identity work at the collective level (e.g., Langley et al., 2013; Schwalbe \& Mason-Schrock, 1996). For example, Langley et al. (2013) showed how health care workers collectively engaged in identity work by enacting new constructions of themselves negotiated in interaction with others. This line of research emphasizes the importance of joint action in (re)creating and 
sustaining the guiding principles that help to (re)define identity, particularly in cases where ambiguity exists (Corley \& Gioia, 2004).

These guiding principles can be conceptualized as institutional logics - "socially constructed, historical patterns of cultural symbols and material practices, including assumptions, values, and beliefs, by which individuals and organizations provide meaning to their daily activity, organize time and space, and reproduce their lives and experiences" (Thornton et al., 2012: 2). In guiding daily activities and life in general, institutional logics provide a theoretically interesting way to conceptualize professional role identities as influenced by societal and field level principles that are intertwined and embedded in various institutional orders (Berger \& Luckmann, 1967; Thornton \& Ocasio, 2008). In highly institutionalized settings, such as health care, the established practices and routines relying on mutual role expectations facilitate the smooth accomplishment of work; however, they also facilitate extreme resiliency in professional role identities, making change exceptionally difficult (Rao, Monin \& Durand, 2003; Pouthier et al., 2013). Consequently, commonly held expectations about the overarching sets of principles (institutional logics) guiding professional work and role identity can help to explain the strong forces that consistently reproduce the status quo. We therefore suggest that a focus on institutional logics can help us understand how change in professional role identity can occur.

\section{Institutional Logics}

Friedland and Alford (1991) introduced the concept of institutional logics into organizational studies as a way of emphasizing the importance of societal context in understanding individual and organizational behavior. They suggested that society is composed of multiple institutional orders, each with its own central logic and "a set of material practices and symbolic constructions" (Friedland \& Alford, 1991: 248). Everyday social life in an 
organization is thus embedded in overarching meaning systems, such as the logic of professions, market, corporation or state. Institutional logics not only guide what social actors want and how to act, but also who or what they are (Lok, 2010:1308).

While early studies explored how a professional role identity is tightly connected with a single dominant logic (e.g., Rao et al., 2003; Townley, 1997) or how different field level actors hold role identities associated with different logics (e.g., Reay \& Hinings, 2009), more recent work suggests a looser coupling between logics and professional role identities (e.g., Lok, 2010; Meyer \& Hammerschmid, 2006). Fields are now commonly characterized as having multiple coexisting logics that exist in combination or are arranged in a constellation (Goodrick \& Reay, 2011; Greenwood et al., 2011). While different institutional logics were previously conceptualized as inherently conflicting, the idea of constellations expanded the repertoire of potential relationships among logics. Scholars have begun to consider the importance of complementary relationships among logics in addition to competitive ones (e.g., Goodrick \& Reay, 2011; Smets \& Jarzabkowski, 2013; Waldorff, Reay, \& Goodrick, 2013). These conceptualizations open up new ways of understanding professional role identity change.

Although many previous studies portray logics as a structural macro influence, newer work suggests that logics must be interpreted by social actors; the meaning of logics and relationships among them are critical to understanding behavior (Currie \& Spyridonidis, 2015; McPherson \& Saunder, 2013; Smets \& Jarzabkowski, 2013; Zilber, 2013). This interpretive perspective of logics is grounded in Friedland and Alford's foundational paper that presented logics as representative of institutional orders, and also argued that logics are "available to organizations and individuals to elaborate" (1991: 248). Consistent with Swidler's (1986) concept of a cultural toolkit, actors can draw on different logics for different reasons and at 
different points in time (Thornton et al., 2012). Swidler also proposed that actors may "know more culture than they use" (1986: 277), suggesting that some logics can lurk in the background rather than be openly adopted. These more active interpretations of logics emphasize the importance of micro foundations in the production and negotiation of meaning (Zilber, 2013) and point to the significance of social interactions in the enactment and instantiation of logics (Thornton et al., 2012). Thus, logics can be interpreted differently by different actors and potentially impact processes of professional role identity change.

By taking a more agentic approach to institutional change, more focus on social interactions is required. Micro-level workplace interactions can amplify and broaden processes of meaning-making to impact large scale change (Fine \& Hallett, 2014; Gray, Purdy \& Ansari, 2015). In addition, it is through processes of frontstage and backstage interactions that individuals develop public and self-images (Goffman, 1969; Jenkins, 1996), suggesting that the place where interactions transpire is significant. Kellogg (2009) showed the importance of the place where interactions occur by identifying the critical relational spaces where reformers developed new identities and enthusiasm for a change initiative. Similarly, recent research has given attention to the venues where logics, their associated practices, and the relationships among logics can be reinterpreted (Smets \& Jarzabkowski, 2013; Smets et al., 2015). For example, in their study of reinsurance trading, Smets et al. (2015) identified the place where underwriters were physically located (e.g., alone in office, interacting with underwriters in confines of their firm, interacting with brokers at the public space of Lloyd's of London) as important in balancing coexisting logics. This interpretive approach in institutional logics studies has provided valuable insights into the micro-level construction of inter-logics relations, but so far it has not been considered in studies of professional role identity. 
Other researchers have highlighted the idea that institutional logics can be used in an agentic way by conceptualizing them as tools (Swidler, 1986). Binder (2007) concluded that the very different response of three departments in one organization to the same institutional logics illustrates that logics are not deterministic; actors are skillful agents that can combine logics, play with them, and take from them as best suits their needs. Similarly, McPherson \& Sauder argued that logics can be "continuously combined, configured, and manipulated to serve the purposes of actors' (2013: 168). They showed how professionals purposefully translated different available logics into action as they negotiated decisions with others. Currie \& Spyridonidis (2015) built on these ideas to show how actors interpreted and employed institutional logics to implement change in the UK National Health Service. By focusing on the micro level, these studies begin to reveal the possible agency of actors in (re)interpreting and using logics to achieve desired goals; however, this agentic approach to logics has not yet been used to understand the dynamics of professional role identity change.

Although we know that professional role identity is guided by a set of overarching principles, and that it is developed and maintained in relationship with other social actors, we still have little knowledge about how professional role identity can change within a highly resilient institutional context. The emerging view of the agentic interpretation and use of institutional logics provides a potentially productive avenue to investigate the identity work involved in professional role identity change. By conceptualizing multiple co-existing logics as available for interpretation and active use by engaged actors, there is opportunity to focus on purposeful interactions and the use of logics to understand changes in the guiding principles of professionals and the work that they do. We build on these concepts in answering our research 
question: How can social actors facilitate change in collective professional role identity by reinterpreting institutional logics and their relationships?

We explore these ideas by focusing on a government-led change initiative to reform primary health care. A key goal of this initiative was to shift family physicians from seeing themselves as autonomous professionals whose practice was isolated from others, to professionals who engage with multiple other professionals as part of a team approach. This change required physicians to alter their professional role identity.

\section{RESEARCH SETTING}

In the Canadian health care system, concern over the steadily increasing cost of care led to a series of attempts to reform primary health care through the 1990 s and early 2000 s. A new approach in one province (Alberta) focused on creating new organizations where physicians would work together with other health professionals to jointly develop new ways to provide care. These organizations were called Primary Care Networks (PCNs); they were established through an agreement among the provincial medical association, the government and the local Regional Health Authorities (RHAs). These PCNs were meant to be sites where innovation could occur promoting more effective local community-based services for patients. There was a particular focus on changing the way services were provided for people with chronic diseases because these conditions were viewed as significant cost drivers for the health system overall. In addition, maternal and child health, and mental health were targeted in some communities as key population-based needs. Therefore, because of quality, manpower and cost concerns, the government wanted to move away from the established system where individual family physicians worked autonomously in their offices, providing services for patients and referring 
them to other professionals when needed. The desired goal was collaborative service delivery by multidisciplinary teams of health professionals (including family physicians).

Special government funding was provided for the parallel development of multiple innovation sites where localized approaches to multi-disciplinary care could be developed. Groups of family physicians were invited to participate in conjunction with their local RHA, and funding was available to hire managers specifically for each PCN. All physicians could choose (or not) to participate. The PCNs were set up to be attractive to physicians - proposals suggested that family physicians could improve work/life balance, improve quality of care for patients, and receive small financial incentives for engaging in planning processes. Physicians were reimbursed for time spent at meetings, program development and other planning activities, that were otherwise not funded. In addition, money was available to hire a wide range of health professionals (e.g. nurses, dieticians, mental health counselors, rehabilitation therapists) who were previously not located in the same office as physicians.

Although this was a government initiative, it built on the long held desires of a few physicians -- 'renegades,' who saw themselves as champions for a new way to practice. They believed that the model of autonomous practice was outdated and inappropriate because it relied on physicians as sole provider, rather than utilizing the skills and knowledge of other health professionals such as nurses, dieticians and pharmacists. As one of our interviewees told us when we first met, "I was one of a few family doctors in Canada [who] have been biding their time and promoting this [collaborative practice] and talking about it. But it never really happened until [the PCN initiative] when all of a sudden somebody said, okay, go! There you are, fellows, go. So I was ready to go" (Physician T1). 
These renegade physicians had been arguing for years that a new model of collaborative care would be better for physicians, patients and the system overall. However, their colleagues were not convinced. As another physician interviewee said, "[Physicians] are working at the max ... and you're asking them to put in this extra time to see how they could change and make it better. But they don't have the time to do that. And so other people are just throwing around ideas and it all ends up being pie in the sky." We were also told, "What physicians are afraid of is suddenly realizing, 'I'm not that person's doctor anymore' - that other people are managing my patient" (Physician T1). Even though the Alberta Medical Association (AMA) was part of the PCN governance structure, they initially remained in the background. Their messages to physicians focused on maintaining professional autonomy, ensuring that physicians retained professional control, and reminding physicians that their participation was "optional" (Alberta Doctors Digest, 2005).

PCN implementation began in 2005. Managers were responsible for arranging meetings, developing plans, hiring staff and engaging physicians. These managers were chosen because they were sophisticated political actors in the health care system. They expected to negotiate difficult waters and make the PCNs viable. Many managers held a combination of health care and business expertise; for example some were registered nurses with an MBA degree. One measure of their success was physician participation -- the number of physicians who 'signed on.' The renegade physicians were key advocates and participants in the initial two PCNs that were established (4\% of physicians). By 2006 approximately $40 \%$ of family physicians in Alberta had joined a PCN. By 2010, the number had increased to $85 \%$ and remained constant through 2012. Although outcome measures in terms of patient improvements are not available, 
by 2010 , physicians and other professionals reported high levels of satisfaction with the new working arrangements and perceived quality of care for patients (Alberta Doctors Digest, 2010).

\section{METHODOLOGY}

Our focus was on analyzing efforts over time to change physicians' collective professional role identity. This study is part of a larger research project investigating changes in primary health care. Three related publications were geared toward health practitioner audiences, addressing managerial implications of organizational change (Reay, Goodrick, Casebeer \& Hinings, 2013; Casebeer \& Reay, 2012) and organizational learning (Reay, GermAnn, Casebeer, Golden-Biddle \& Hinings, forthcoming). Another publication contrasted change initiatives in primary health care in Denmark with those in Alberta (Waldorff, Reay \& Goodrick, 2013). Overall, the broader research project facilitated attention to multiple facets of health system change. In this study, we focused on changes in professional role identity and drew on the concept of 'constellations of logics' to guide our analysis. In addition to following events in the field over a four year period of time, we engaged in a comprehensive review of publicly available documents generated before, during and after our field work. We followed a process theory approach, giving particular attention to the series of events and actions over time (Langley, 1999; Poole, 2004).

\section{Data collection}

We gathered interview data from key actors (physicians, other health professionals and managers) involved in designing and implementing PCNs. A total of 162 interviews were conducted at four points in time (T0, T1, T2, and T3) from 2005 to 2008. (See Table 1.) Thus we captured actor interpretations pre-initiative (T0), and throughout the change process, including the early start (T1), when expectations were contested, and at two later points (T2 and T3) when 
practices were intended to have spread throughout the population of family physicians. At T0, we learned that physicians were mostly skeptical (at best) of the proposed changes, but a small number of 'renegade physicians' were early proponents of the new model. We interviewed the same physicians over time - initially a mix of renegades and those who were reluctant to change. By the end of our study, all physicians we interviewed had engaged with the new model.

Most managers and other professionals were also interviewed at each time point. In some cases, people had changed positions; if so, we interviewed the person taking over that position. Interviews were conducted at the clinic or office where people worked, and we often received a short tour of their work space. Our physician interviews were usually scheduled as clinic appointments -- typically over lunchtime or at the end of the day. All interviews were semistructured with open-ended questions to encourage descriptions and explanations without imposing constraints. All interviews were recorded and transcribed verbatim.

To gain a better sense of the field level, we also collected and reviewed documents prepared by the government, the AMA and the PCN sites. In addition, we conducted a systematic search of all newspaper articles published in relevant cities between 2004 and 2012. Although our interview data collection ended in 2009 , we gained broader and longer term information about the change initiative by reviewing these archival documents. In all cases, we focused on the professional role identity of family physicians in relationship to the primary health care reform initiative. The documents provided background information and data about the actions and responses of key field level actors - including government, the AMA and other health associations. Table 1 shows the type and quantity of data collected over time.

[Table 1 about here]

\section{Data analysis}


We analyzed the interview data in parallel with the archival data. The first author together with a research assistant compiled the raw data (interview transcripts and observational notes from meetings) and entered it into NVivo (qualitative software). We then engaged in open coding that drew our attention to changes in physicians' views about their work and what it meant to be a physician. We particularly noted how managers and other professionals were involved in this process. We compared these initial analyses with text in documents (medical association newsletters, government reports and newspapers), and refined the coding schemes over time as we identified particular patterns. In developing these categories we read and re-read the transcripts and archival documents iteratively with the extant literature, engaging a constant comparative frame for our research (Locke, 2003; Glaser \& Strauss, 1967).

Our first analytical task was to understand what professional role identities physicians held and whether these role identities changed over time. To do this we drew on the seven societal level institutional logics (professional, market, corporate, community, state, family, and religion). First we ascertained that professional, market, corporate, and state logics were most important in our setting. Table 2 shows our analytic framework with the key aspects of each logic (modified from Thornton et al., 2012) and the associated professional role identity for each of the "ideal types". Following Reay and Jones (2016), we evaluated the strength of each logic in comparison to the "ideal type" as a constant comparator. As Thornton et al. point out, the "ideal type" analysis is an initial step to "help the researcher avoid getting bogged down in merely reproducing the often-confusing empirical situation" (2012: 52).

[Table 2 about here]

Determining the "ideal type" professional role identity for each of the logics relies on an abstraction of concepts from the literature to infer the role identity a physician would 
theoretically hold if a single logic were the only one guiding how physicians see themselves and the work they do. For example, if guided only by the professional logic, physicians would rely only on their own expert knowledge to conduct their practice, thus holding complete professional autonomy and control over the content and organization of work (Freidson, 2001; Thornton et al., 2012). This means that in the professional ideal type, physicians would see themselves as experts holding unique knowledge who make independent decisions about patient treatment based only on their own evaluation of patient need. In contrast, if guided only by the market logic, physician expertise is a commodity, subject to the principle of free trade and maximization of profit. In this 'ideal type' physicians would see themselves as the holder of a rare or unique resource that could be maximized for financial gain. If guided only by the corporate logic, physicians would see themselves as members of an organization where their position of authority and ability to make decisions about patient treatment is controlled by established organizational rules. If guided solely by the state logic, physicians would see themselves as government representatives with responsibilities to provide equal service for all while striving to improve population health. Clearly, these ideal types do not exist in reality. Instead, they serve as important comparators in exploring how different institutional logics guide physicians’ professional role identities over time. We evaluated closeness to ideal type for each of the relevant logics (professional, market, corporate and state) guiding professional role identity at the beginning of our study (T0) and at the end (T3). This evaluation revealed differences associated with the initial professional role identity (autonomous expert), compared with that at the conclusion of our study (head of the team).

Our second analytical task focused on understanding how the changes in physicians' professional role identity were accomplished. Here our interest was in how physicians and others 
changed their views about the physician role identity and their work practices. Since we identified a different constellation of logics guiding professional role identity at the beginning of our study compared to that at the end of our study, we wanted to understand how this change in logics occurred. Thus we followed an interpretive approach to analyzing our qualitative data in order to understand how this new constellation of logics was developed, and how professional role identity was changed (Golden-Biddle \& Locke, 2007; Locke, 2003; Stake, 1995).

We focused our attention on the ways in which key actors (physicians, other health professionals, managers and the medical association) interacted with each other. This was motivated by established theory about professional role identity and institutional logics which pointed to the importance of interactions and by interviewees' portrayal of PCN development. Our interviewees told us about various types of spaces and events where people met and participated in discussions and negotiations about what it meant to be a professional. These included group situations such as planning meetings, and also one-on-one meetings such as hallway, office or telephone interactions. Consequently, we analyzed our data identifying first and second order themes, with attention to the interactions interviewees told us about and the type and range of actors involved in these interactions. The first author inductively coded data, engaging other authors in successive rounds of discussion involving ongoing iteration between data and the extant literature (Cresswell, 2013; Myers, 2013). Through this process we became focused on how actors interacted to co-create a new professional role identity for physicians and how logics and the relationships among logics were re-interpreted through these interactions. Our coding structure is set out in Figure 1.

[Figure 1 about here] 


\section{CHANGING WHAT IT MEANS TO BE A FAMILY PHYSICIAN}

In the following section we present our findings about professional role identity change over time. First, we show the differences in physician role identity at the beginning of our study compared to the later stages, and explain these different professional role identities in terms of an altered constellation of logics. Second, we explain our analysis of how changes in the guiding logics were accomplished over time through different types of orchestrated interactions.

\section{Changes in Physician Role Identity}

At the beginning of our study (T0, early 2005), when the change initiative was just being developed, our interviews with family physicians and our analysis of documents from that time period showed that the predominant view of physician role identity was what we label an 'autonomous expert' who independently provided care for his or her patients, referring them to other professionals if and when required. The opening quote for our paper illustrates this, and similarly the following quote shows the common physician view:

Physicians know medicine. So you just have to do what you have to do. You see patients and do your best. All the doctors are each on their own. But we don't want to share. They don't want to share information; they don't want to share patients. (Physician, T0)

In terms of a comparison with the ideal types of the professional, market, corporate and state logics (as shown in Table 2), the autonomous expert was guided by a constellation of logics in which we evaluated the influence of the professional logic as very strong, the state logic as low, the corporate logic as low, and the market logic as low and hidden. We explain this evaluation below and provide illustrative quotes.

We evaluated statements made by physicians in interviews and text presented in the medical association documents as highly consistent with the ideal type of the professional logic (unique expertise used to make decisions for patients), and therefore we rated the strength of the 
professional logic as high. For example, physicians said, "We always focus on what we see that our patients need," and "We make decisions based on our medical knowledge." Examples of text in AMA documents are: "Physicians must hold a great deal of control over the responsibility and delivery of services," and "Physician professional autonomy is essential." Regarding the market logic, physicians seldom spoke of financial motivations. This suggests that they did not see themselves as being influenced by the market logic (that physicians made decisions based on gaining the greatest financial return for their expert knowledge) and thus we evaluated the strength of the market logic as low in comparison to the ideal type. Physicians told us that they treated patients, and then "our administrators bill the government for our services." However, we heard from others (managers in particular) that physicians worked longer hours to increase their income, and that they worried about new models of care involving nurse practitioners because they might take patients away from physicians, thus reducing physician income. This led us to characterize the influence of the market logic as hidden.

We also evaluated the influence of the corporate and state logics as low, because physicians told us they were very much opposed to being part of either the organizational bureaucracy, or being part of the government. "Doctors hate meetings. And we hate all the hierarchy that goes with the regional health authorities - we have to be apart from that!" We were also told, "We're proudly separate from the government! We have to be able to stand up for our patients!" Physicians' view of themselves was not at all close to the ideal type for either the corporate or state logics - leading us to evaluate the strength of both these logics as low.

By the end of our field study (2009), collective physician role identity was different from that at the beginning. Instead of thinking of themselves as autonomous experts who worked independently to provide care for patients, physicians described a new role identity as one where 
they saw themselves as part of a team, trusting other health professionals to carry out particular components of care, but where physicians were always informed about care provided and progress of the patient. We labeled their new professional role identity as 'head of the team' as illustrated by our second opening quote. For example, a physician told us, "we now have nursedoctor dyads, teams with pharmacy backup, social workers, mental health navigators - it's a new world where we rely on others to make it all work." This was a significant change for physicians; they 'gave up' many tasks, reducing their contact with patients and many aspects of control. The constellation of logics guiding this new professional role identity was changed so that in comparison to the ideal types for each logic, we made the following evaluations: the influence of the professional logic remained strong but was reframed, the state logic increased to moderate, the corporate logic remained low and its conflict with the professional logic was reinforced, and of particular note, the influence of the market logic became moderate and no longer hidden.

We evaluated the professional logic as strong (close to the ideal type) because physicians continued to see themselves as experts holding unique knowledge, making decisions for patients based on that expert knowledge. They viewed health professionals on the team as helpful additions, who took over less difficult tasks:

Physicians are still the most important, but the nurse currently in the office is very helpful. We're using them to [conduct various procedures] and we follow up with actual medical care. (Physician T3)

[I wasn't a supporter at the beginning] but it certainly has made doctors think differently and has made me think differently. And I think it's in the long run going to help hardworking physicians not burn out. Because they are going to be able to spread out some of the services that they were offering and realize that they don't have to do everything for everybody... but do the stuff that they're trained to do. (Physician T3). 
In evaluating the strength of the market logic, we heard physicians speaking much more openly about the influence of financial incentives on their behavior. This led us to assess the strength as moderate, and no longer hidden. The following quotes illustrate:

[Things have changed].. now you get money if you offer [a particular service] and have [other services] in place, then you get $\mathrm{x}$ amount per population. The PCN helps us organize to take advantage of this. (Physician T3)

This new PCN will pay us to come together with others to vision ... we've never done that [be paid for participating] in our whole history before... It means that we are attending planning meetings. (Physician T3)

In terms of assessing the strength of the state logic, we heard much more interest from physicians in managing their practices to increase access for patients generally - an important component of the ideal type state logic. For example,

We give more complete care .. Educating patients more .. Patient care (overall) is improving.. And now patients are actually managing for themselves (reducing access concerns). It all means that we can reduce wait lists and improve overall access. (Physician T3)

And finally, with regard to the corporate logic, we continued to hear severe opposition to being guided by organizational rules or hierarchical decision-makers. We therefore evaluated the strength of the corporate logic as remaining low.

We have got to stay away from this overwhelming stream of accountability.. [The health region] wants more and more forms filled out. [We have to] get it the hell off the plate of physicians, because it's a brutal waste of time and energy! (Physician T3)

Based on the nascent literature concerning both professional role identity and institutional logics, we focused on trying to understand how this change in collective professional role identity and the guiding constellation of logics occurred. To do so, we analyzed document and interview data to develop a model of how different actors engaged with each other to facilitate change over time as explained in the following section. 


\section{Re-interpreting and Re-arranging Institutional Logics}

Our analyses revealed four mechanisms that occurred over time and collectively served to rearrange the constellation of logics guiding physician role identity: (1) revealing the influence of a hidden logic, (2) reinforcing the conflict between two conflicting logics, (3) reframing the meaning of a dominant logic, and (4) re-embedding the new arrangement of logics. Each mechanism emerged through interactions among key actors (renegade physicians, other physicians, managers, nurses, and other health care professionals). We particularly noted how managers instigated and orchestrated many interactions; they had been charged with leading the reform initiative and we observed that planning for, and facilitating interactions was at the heart of their managerial work. The renegade physicians were also critical participants. They interacted directly with other physicians who were initially reluctant to engage, and also strategized with managers about the best ways to gain support from skeptical physicians.

Below we show our analysis of how the four mechanisms of re-interpreting and thus rearranging logics were enacted through interactions among actors over time. We present our findings in accordance with the overall changes that we observed; however, there were certainly missteps and backsliding along the way. Managers varied in their abilities to arrange and orchestrate different types of interactions. Some health professionals were more engaged than others, and not all physicians changed their professional role identity at the same time. But overall we observed changes that resulted in a different collective physician role identity at the end of our study compared to the beginning. Our attention was particularly drawn to interactions, both empirically and theoretically; the institutionalized nature of our context highlighted the relational aspects of professional role identity evident in workplace relationships among professionals. Thus our attention was drawn to particular types of interactions that were 
important to the process of re-arranging the guiding constellation of logics and altering physicians' professional role identity.

\section{Revealing the influence of a hidden logic. [Physicians consider new role identity]}

The first stages of the PCN initiative required that physicians step forward and formally agree to try the new model; however, most were skeptical about changing. Financial incentives to encourage participation were embedded in the new model, but open discussion of physicians being enticed by money (market logic) was typically taboo because it conflicted with the tenets of professionalism. In the old system (pre-PCN), physicians submitted a bill to the government for every patient they saw; thus, they maximized their income by seeing as many patients as possible. However, neither physicians nor the AMA mentioned the financial benefits accrued from seeing many patients, since it was contrary to the professional logic with its strong emphasis on service and altruistic approaches (hidden market logic).

In our first round of interviews, we heard about meetings organized by managers in collusion with renegade physicians to facilitate broad physician engagement by drawing attention to the value of available financial incentives. There were two main types of interactions: (1) informal private meetings where physicians and managers engaged in off-record conversations to talk through physician participation in the PCN, and (2) formal workshops that brought together physicians, managers and other health care providers to discuss how primary health care services should be organized within the PCN. Both the private and more public meetings provided space for sharing financial and organizing information; the private discussions facilitated frank negotiations where physicians reflected on the potential to practice differently and also increase their income, while the team meetings created space for physicians and other professionals to consider a new model of care. 
The nature of discussions in both types of meetings revealed the influence of the market logic to physicians themselves and to other professionals. This occurred in two ways. First, the effect of financial incentives on physician behavior became clear when physicians turned out in record numbers for team meetings where they were paid an hourly rate. This was in stark comparison to previous meetings where physicians virtually never attended. Their paid presence was openly discussed among physicians, managers and other professionals as the following quotes show:

We don't usually talk about money, but we needed to have resources to bring physicians together with other professionals, and we were fortunate to have that. It created an opportunity to come together, and to pay for things that weren't otherwise remunerated. For instance, to get physicians to actually come to a meeting it was important to compensate them financially. (Manager T0)

[In this new model] Physicians get paid to go to meetings. Not bad! I fully support that, because everybody else at a meeting is getting paid - why not the docs? It's not a lot of money in the end, but it's a huge issue. (Physician T1)

I hate to say it, but it seems that when you've got funding, and money came into the equation, that had a lot to do with people getting on board. (Physician T1)

Managers told us that in their private conversations with physicians, in contrast to the past where physician compensation was almost never discussed, they began to talk openly about the importance of financial compensation (market logic) to physicians.

When we were able to tell them what others were getting for personal physician compensation to change the way they practice, they seemed to think - oh, okay, you want us to be compensated for practicing differently. And then we could hammer out the things that needed to happen, how dollars were associated with that, and what different models would look like. (Manager T1)

[In one of our discussions] a physician said, 'You guys don't value what I do. You don't think we do a good job.' And we said, 'We do! We think you do a really great job.' And then we sat at the table, and asked, 'What is really the problem here? What do you want?' and eventually he articulated a need for personal benefit. So when we could finally talk openly about physician personal benefit, we started to be able to hammer out how things could happen. (Manager T1) 
The second way that the influence of the market logic was revealed was through arguments designed to convince physicians that financial incentives were important in improving patient care. Managers and sometimes other health professionals proposed strategies to align physician remuneration with improved service provision. These arguments were made specifically in private manager - physician conversations and reinforced in the more open multidisciplinary workshops.

In their private meetings with physicians, managers and renegade physicians focused intently on principles associated with the market and professional logics, arguing that successful reform relied on physicians seeing themselves as guided by both professional and market principles. The private nature of these discussions allowed frank explanations about ways that financial incentives could drive physician behavior:

You talk to docs, explain that you guys get this money and make decisions, this money goes here, and this is why. [they say] "Oh, cool. This is great. I can't believe it." So you want to make it simple for people to understand funding and accountability. (Manager T1)

This led to new insights for physicians.

There were palliative patients who didn't have physicians anymore. Their doctors said they're too busy to do palliative care. But the PCNs can now pay physicians [extra] to do that, and we're seeing much better uptake [which is important for patients]. (Physician T1)

As the ideas about linking physician incentives with better patient care became increasingly discussed at group meetings, other professionals began to propose new suggestions about how to improve care.

The meetings helped us understand physician arrangements - especially financial issues about after-hours physician services. The [palliative] nursing staff had been feeling unsupported by physicians [but we learned more about physician remuneration] and we were able to propose solutions. (Nurse T1)

Private, protected interactions encouraged attention to financial rewards (market logic) in addition to professional values. It was important that these interactions were non-threatening to 
physicians since they had to be enticed into the initiative - they could not be forced to engage. However, once physicians began to think differently about how they organized their time and their practices, they began to see new possibilities about how to be a physician. Many started thinking more strategically, seeing themselves as holding a valuable resource (knowledge, consistent with the market logic) and engaging in decision-making processes, often together with managers, to determine the best ways to maximize their financial returns while providing even better care to their patients. For example,

A number of us [physicians] have now been through [an office management] program. We're learning the financial implications of different structures, and different ways to use physician resources. We're kind of starting to ask questions about work flows and service structures, and how physicians fit into all this. It's a whole different way to practice medicine. (Physician T2)

Revealing the previously hidden influence of the market logic allowed physicians to reinterpret the relationship between the professional and market logics as more complementary instead of conflicting which opened new possibilities for physicians' role identity. Private interactions between physicians and managers or renegade physicians opened up possibilities for change driven by financial incentives, and open discussions in team meetings facilitated new ways of thinking about physician work and their identity. Physicians began to see that they were more similar to other professionals than they previously thought—all were motivated by a combination of financial and professional values. These interactions supported the development of new relationships between the market and professional logics in guiding physicians' role identity, and because of the open discussions, these changes were collectively viewed as appropriate. The AMA was notably absent from discussions revealing the influence of the market logic; it continued to focus on values associated with the professional logic. 


\section{Reinforcing the conflict between logics [Physicians clarify who they are/ who they are not]}

After physicians formally agreed to be part of the PCN ('signed on'), the next step was to develop official business plans required by government before funding could be released. We observed that in this second mechanism -- reinforcing the conflict between logics -- managers pushed further on physician engagement by drawing their attention to what work physicians should do in the new model, and what they should not do. As part of this process, physicians also began to determine what kind of professional they would be, and what they would not be.

From a logics perspective, managers conversed with physicians about the need for (and distinction between) work within the PCN that was aligned with the corporate logic (e.g. financial planning, supervision of staff) and other work aligned with the professional logic (e.g. diagnosis, treatment, patient teaching). Also, through mutual agreement, managerial work became more clearly separated from physician work. Collectively, managers and physicians reinforced and strengthened the conflicting relationship between the professional logic and the corporate logic in the constellation guiding physician work and identity.

We heard about two types of interactions through which this mechanism was accomplished. The first was formal business planning meetings, restricted to physicians and managers, designed to establish priority initiatives (such as particular chronic care programs or maternal wellness projects) and clear financial plans to achieve the desired goals. They were organized by managers and held outside of regular clinic hours; physicians were compensated for attending, resulting in high physician participation. The second type of interactions during this phase was one-on-one meetings between AMA representatives and physicians, and follow up one-on-one meetings between physicians and managers. These interactions were driven by an AMA initiative to remind physicians about their legal and professional responsibilities. 
We identified two ways this mechanism of reinforcing the conflict between the professional and corporate logic occurred. First, managers protected physicians from taking on administrative activities, focusing on physicians' desire to "be physicians, not managers." This happened during business planning meetings when managers played up physicians' frustrations about the time-consuming nature of 'corporate' type activities, and offered to help by taking over administrative work, as shown below:

Physicians couldn't do the business plan, and we didn't want them to -- that's what I had to work with to start out. And there were legal agreements, how this would all work. And then how it actually functions. (Manager T1)

[We realized] there are going to be accountability measures that we have to submit to [government] and the PCN committee and if those aren't met, of course then there'll be hard questions asked. Physicians can't take time to do this, and we don't want to... We don't want to be bureaucrats. (Physician T1)

Managers used physicians' dislike of administrative work as an opportunity to strengthen the importance and value of managerial work, keeping that work for themselves; thus they built up the expectation that physicians should remain focused on 'physician work' and stay separated from day-to-day management concerns (managerial work):

I made sure that I took care of doing the leases and legal agreements, and setting out what staff contracts should look like - and also contracts for physician temporary replacements for holidays - all those kinds of things that had to be in place, so that physicians don't even need to see all that work. (Manager T1)

Well, from a medical point of view, we're trained as doctors and our goal is to do medicine. So we want to practice medicine. It makes no sense to have us, somebody trained in medicine, doing all of our administrative work. So our hope is that [our manager] will help set up programs, she will keep the clinicians doing what they do best and where they should be, so that we can actually just provide care. (Physician T1)

The second way that managers maintained the conflict and separation between the corporate and professional logics was by distinguishing physicians as highly specialized experts who were required for medical, not managerial work. This purposeful focusing by managers 
occurred in response to an initiative by the medical association (AMA) to engage in a series of interventions to ensure that physicians remained aware of, and continued to meet their professional responsibilities within the new workplace dynamics. The AMA provided overarching advice through printed and website newsletters and communiques that set out physicians' professional obligations -- in particular, physicians' responsibility 'to act in the best interest of the patient' and ensure quality of care (Alberta Doctors' Digest, 2005). In addition, the AMA sent representatives to meet with physicians in their clinics -- individually or in small groups. These directly targeted interactions consistently raised concerns that physicians might lose professional autonomy and control by allowing others to manage patient care. Physician interviewees told us that the AMA kept them focused on insurance and liability issues, consistently warning of potential dangers. Physicians said that they listened carefully to the AMA's concerns, and they were more leery of full participation in the PCN as a result.

Yeah, I know right from the start, when this was first discussed with the AMA representatives, I said, well, I said, I don't think this is going to work terribly well in a lot of situations... I don't know how I can keep track of patients .. Right now I'm trying to grab my patients now when they come in and say, oh, lookit, you last had a complete exam three years ago. Do you think maybe it's time? (Physician T2)

The AMA's position on professional responsibility was interpreted by some as warning physicians about the dangers of relying on others (i.e. managers) to organize delivery of care; however, many managers were able to follow up through one-on-one conversations suggesting that by avoiding managerial work, physicians could increase professionalism and improve their work life. This reframing of the AMA message was intended to encourage physicians to trust managers to do manager work, allowing physicians to do physician work even better.

The physicians had had meetings with their practice management person from the AMA. They decided the priorities [what was essential for physicians], from their [professional] perspective. The focus was always on the physician - patient relationship. We kept 
encouraging physicians to do the work that only physicians could do, and let us managers take care of the managing part. (Manager T1)

Many physicians, but not all, found ways to reconcile the somewhat disparate messages of the AMA and managers by taking the position that "we are physicians, not managers." They could therefore move forward with engagement in the PCN. Other physicians were put off by concerns expressed by the AMA, and delayed participation as a result. Those already committed to the PCN initiative, or who were swayed by the managers' arguments to take more pride in being a physician by distinguishing themselves from managers, explained:

It's not a battle, but it's simply a discussion around the obligations of care that we can defend - so we can focus on what we need to do. And not be diverted. (Physician T2)

Overall, we see that one-on-one interactions (managers or renegade physicians encouraging physicians to be 'better' physicians by giving up managerial responsibilities) were critical in strengthening the separation between the professional and corporate logics. Within these relatively private conversations, more physicians became convinced that it was advantageous to focus more clearly on the professional logic, developing a sense of "who they were' (physicians) and 'who they were not' (managers). This was in strong contrast to the autonomous physician model of the past. As physicians decided they could be 'better physicians' by sticking to physician work, they began to see themselves as highly specialized professionals who focused only on highly professional work, and were supported by others who took on work related to the rule-bound norms of the corporate logic. As part of this new view, physicians began to see managers as organizational experts who managed bureaucracy, reinforcing the separation of the corporate logic from the constellation guiding physician role identity. 


\section{Reframing the meaning of a dominant logic [Re-negotiating physicians'sense of}

\section{professionalism]}

After the business plans were developed, submitted to the government, and funds were consequently released to the PCNs, the more difficult work of actually changing services began. The goal was to integrate physicians with other professionals instead of them working alone. In the case of diabetes care, for example, nurses were hired and located in physician clinics where the onus was on nurses to find ways to engage in components of care such as patient education, routine check-ups and general oversight of patient well-being. Dieticians, exercise therapists and pharmacists were also brought into the team, usually on a part-time basis to provide additional services. Instead of others fitting their work around physicians (as was the case prior to the PCNs), physicians' work had to fit in with everyone else. This was not easy. Although physicians had agreed in principle to the establishment of these new work arrangements, many became concerned about the disruptions and loss of control when the changes actually occurred. This phase of the initiative was when we identified the importance of the mechanism of reframing the meaning of the dominant (professional) logic.

It was during the implementation of new integrated work arrangements, procedures and division of responsibilities that managers, renegade physicians and other professionals engaged in almost continual interactions to attempt to convince the bulk of physicians that they could be part of the PCN and still maintain their sense of professionalism (strong professional logic). This was accomplished through interactions that served to reframe the meaning of the professional logic in ways that could accommodate team based medicine. We saw that there were three types of interactions where this occurred: (1) unscheduled one-to-one manager-physician, or renegade 
physician-physician meetings, (2) discussions and physical coordination of work routines among physicians, nurses and managers, and (3) scheduled PCN team meetings.

We identified three different ways of reframing the professional logic. First, we heard how managers and renegade physicians expounded on the importance of physician expertise to convince physicians that other health professionals should take on many tasks previously designated as physician work. This convincing process occurred particularly in the privacy of one-on-one meetings between managers and physicians, and also those between renegade and other physicians. Although teamwork involving multiple professionals is contrary to the principles of autonomous decision-making (professional logic), managers and renegade physicians dismissed this interpretation and presented teamwork as strongly aligned with the professional logic. They emphasized how the new model kept physicians central to decisionmaking by right of their expert knowledge. Other professionals were presented as helpers, 'extra arms and legs' for the physician, and as 'physician support' in complex patient care.

This new model allows physicians to really focus on what they want to do. For instance, we now do pediatric screening programs, teen health. And it all means that physicians stay on top of things by relying on others. (Physician T3)

Praising physician skill and expertise was also done by other professionals as part of exchanges that occurred in the workplace. These interactions were less private, but restricted to team members. For example, nurses told us about their efforts to take over some tasks - their arguments began by explaining to physicians how physician expertise should be reserved for the most complex cases. Nurses purposefully made themselves available in the clinic to opportunistically and helpfully take over an increasing number of tasks. For example,

We [nurses] started working in clinics and right away realized that relationship building is key -- between the nurse and the physician. A big portion of the nurse's time was consumed in preparing the clinic, sorting out how things will work. [We had to keep 
explaining] our nursing knowledge allows us to do these tasks. [We kept telling them]

'We're not duplicating services. We're enhancing physician services.' (Nurse T2)

Although they had some initial reluctance, physicians began to see benefits:

And if our nurses can have encounters with 10 percent of our patient population in the first year, that's pretty good, and if we can see that going up, we know that we're - we are providing a service that is valuable to our community and that, in turn, that in and of itself, makes doctors feel that this is worthwhile. (Physician T2)

The second way the professional logic was reframed was through arguments designed to re-define control as 'staying informed,' instead of holding autonomy. Managers engaged in private conversations with physicians to develop ideas about how to operationally keep physicians informed. Managers then worked with physicians and other professionals to develop reporting requirements and routines that allowed other professionals to provide physicians with regular updates. The relocation of nurses and other professionals into physician clinics was critical, because it showed the physicians how well the reporting system could work. Managers continued to make the argument that physicians were in control of patient care, and in workplace interactions, other professionals confirmed this by consistently keeping physicians informed.

Because nurses and others were physically located in close proximity to physicians, they had the potential for multiple points of interaction throughout the work day, and most of them took full advantage, as shown below:

We focused on building that role with the physician. If you don't have that relationship, it doesn't matter how good you are, you have to have forged the relationship. So my job has been to teach nurses not only how to be good [primary care] nurses, but also to make their work interface well with physicians. They need to see how it's all going to fit together, and how our work makes him a better physician. (Nurse T3)

We are [often] asked by physicians to [consider] a patient's set of medications -- if we think it's necessary to add a medication, or change a dose of a current medication, or stop a medication. It's important that we build our reputation .. success breeds success... You get to know your physicians. And you learn how ready they are to hear your opinion -- How much freedom you have. And you build that by keeping them informed and by building those relationships. (Pharmacist T3) 
Managers were very strategic about this work:

When we introduce nurses into clinics we sit down with them [physicians] and we say, 'This is the training the nurses have. These are the things they can do. These are the tools they're going to use to do it.' In some clinics it has taken up to a year to get the clinic prepared for the nurse. (Manager T2)

And physicians began to see the value:

...the nurses have a certain protocol that they're following with patients. So I'm aware of what they're going to be telling the patient. And I'm then feeling very comfortable, those aren't areas I have to go over, they're looked after. Same with the dietician, pharmacists, all of those elements are always very, very helpful. Because you know what's going to be done by the different team members is going to be evidence based. And I really actually appreciate that very much. It helps me be a better physician. (Physician T3)

Not all nurses proved to be skilled at convincing physicians to see themselves differently.

Managers told us that it took a special kind of nurse to not only engage in his or her nursing work, but also engage with physicians to help move them into a new way of working and a new role identity. Some nurses had their employment terminated because they lacked the sophisticated social skills needed to facilitate physician participation in the new model.

None of our nurses are used to working with a family doctor where there's no protocols on anything. They have to be resourceful and find ways to engage with the docs. Not everyone can do it - and we did have to let some of them go because it just wasn't working. (Manager T2)

Not all managers were sufficiently skilled either. Over the course of our study, several managers failed to bring physicians and other professionals together in effective ways. In one case a manager was eventually re-assigned to a different part of the system. In another case the manager was terminated after lack of progress. But the majority of managers and other professionals became increasingly skilled at orchestrating interactions that shifted physician focus away from autonomy (a key aspect of the professional logic) toward staying informed; the associated reporting requirements could have been perceived as affiliated with the corporate 
logic - but were not. Instead, physicians accepted 'being informed' as a proxy for control over patient care, agreeing with the reasoning that they "couldn't do everything." They told us that "it actually works out pretty well - the team tells me what's happening with new diabetics (for example), and I can keep control over my patients that way."

It's a huge change for me and my practice. Patients get advice in other areas [drug formulary, dietary things] and it's readily available. They [other professionals] just keep me informed. And it reduces the amount of work that the physician has to do, and I think that it improves patient care at the same time. (Physician T3)

The third way of reframing the meaning of the professional logic was by construing professionalism as responsibility for overall population health by ensuring the availability of quality services. Managers and renegade physicians made these arguments as they engaged with physicians in private one-on-one conversations and in the more open space of regular PCN team meetings. Managers and renegade physicians justified the PCN initiative as a means to enhance physician practice by providing high quality services for more patients. Ensuring access to health care for all citizens is a key component of the state logic, however managers explained to us that in team meetings, they used the numbers of patients served as important indicators that the PCN was successfully providing quality services for their immediate population base.

We are placing a lot of emphasis on measuring patient access -- how quickly can you get in to see your physician? When you're in to see your physician, how much time do you just sit around waiting for something to happen? Our numbers are improving and we keep reminding physicians of that. (Manager T3)

These convincing strategies seemed to work. In the later stages of our interviews, physicians told us about their views of professionalism, suggesting that being a good doctor was linked to the number of patients served.

There are two goals to primary care renewal - and they are everybody's goals.. funders, doctors, everyone.. Increased access - that means people get to see a doctor when they need to, and there's a doctor who will see them. (Physician T3) 
We see that this mechanism of reframing the meaning of the professional logic was at the heart of changing the physicians' professional role identity. While the first two mechanisms facilitated consideration and basic terms of changing, it was in this third mechanism where interactions associated with workplace practices (physicians together with other health professionals) facilitated the renegotiation of how physicians saw themselves and how they did their work. Private discussions and more open team-based interactions pushed attention to the best use of physician expertise and 'being informed' as sufficient indication of physician control. As a result, physicians and others could embrace the new role identity of physicians as 'head of team' by highlighting some aspects of the professional logic (expert knowledge, recognized status and responsibility) and downplaying other aspects (autonomous decision-making, control over quality) that could be satisfied by keeping physicians informed.

\section{Re-embedding the new arrangement of logics [Sustaining new physician role identity]}

As the workplace changes began to be realized and physicians agreed (sometimes grudgingly) that they actually enjoyed their work more, patients were happier with the new team approach and their clinics were running smoothly with managers handling administration, attention turned to the sustainability of the new model. Managers in particular, recognized the importance of finding ways to re-embed the new model into self-perpetuating systems and practices to reduce the opportunities for physicians to revert back to their autonomous role identity. As part of this quest, we heard about 'standardized care' (an international approach to health care based on pre-determined protocols and established pathways of treatment) as an important strategy. Standardized care had been part of the PCN model from the outset, however, 
it was only toward the end of our study that we saw how its implementation served to reinforce the new arrangement of logics associated with the 'head of team' professional role identity.

Standardized care stands in contrast to the principle of professional discretion (a hallmark of the professional logic) because it is based on the development of efficient standardized care paths for conditions such as diabetes or chronic lung disease. These standards are based on research evidence and the approach is closely aligned with international efforts to promote evidence-based medicine. Following pre-determined rules associated with standardized care could be characterized as consistent with a corporate logic; but the principles instead were presented as contributing to quality of care (professional logic), and increased access for patients (state logic) that consequently resulted in an increase in revenues for clinics and physicians (market logic). Thus, the implementation of standardized care served to reinforce the "head of team' professional role identity and the new arrangement of logics. This occurred in two ways.

First, the new professional role identity was reinforced through a focus on the evidencebased nature of protocols and guidelines (grounded in the most up-to-date research) and their links to quality of care. These connections to quality (professional logic) were explicitly made in the regularly scheduled meetings set up by managers with physicians and other health professionals to review data related to PCN patient outcomes. These meetings had previously been the place where managers portrayed PCN success in terms of increasing number of patients served. With information about overall improvement in patient health indicators, the focus shifted success to include quality in addition to volume. Team members (including physicians) collectively developed a sense of pride in reviewing health indicators (e.g. blood sugar levels).

When I had the most recent statistics on patient outcomes, I organized a meeting of everyone - physicians and other professionals. And I showed them the data from before compared to now. There was a huge difference! It made people say, ok, what I'm doing is making a difference! So now I think that they've [physicians] bought into it. (Manager T3) 
I'm working in this model [PCN]. I'm seeing way more people than I ever did, providing more service and increasing accessibility to me. And it's working really, really well that way. (Physician T2)

The second way the new constellation of logics was re-embedded was by linking multidisciplinary teamwork with improved flow-through of patients and increased clinic revenues. In regularly scheduled meetings, managers developed the agenda with time for physicians and others to review monthly changes in the total number of patients receiving treatment -- consistent with the state logic's emphasis on access. This focus on patient volume was popular with physicians because it also aligned with the market logic; more patients at the clinics translated into increased revenues for the physicians. Managers told us that they also discussed the importance of improved physician lifestyles when they met with them in one-onone meetings; they consistently reminded physicians that the new model gave them more control over their own time, and that this meant better sustainability overall.

We really believe that there has been marked improvement in terms of accessibility, the use of multidisciplinary teams, the coordination of care, the continuity of care has been better, physicians' lifestyle has improved. (Manager T3)

The physicians gave us similar accounts:

We said that in our PCN, [the new protocols] have to improve access and care for patients. Not only that - but it's got to improve doctors' lifestyles, because there is a shortage [of physicians]. So whatever we do has to meet those two objectives - has to improve patient care and make things better for our group as a whole. .. We think we're getting there. (Physician T3)

I've got to give credit to our Business manager. [He's got us] talking about improving efficiency in the office, and using other business terms - like what is the supply, what is the demand? Can we lower the demand on physicians by letting someone else do some of their work? .. And it's all translating into more patient through-put and better revenues in the clinics. (Physician T3)

Re-embedding the new constellation of logics also required a shift in guiding values and principles at the medical association (AMA). Physicians continued to interact with AMA 
representatives during this stage in our study. However, instead of the previously constant messaging from the AMA to physicians regarding risks to professional autonomy arising from a team based approach and the sanctity of the physician - patient relationship, we heard about physicians taking the initiative to tell the AMA it was time to support them.

We had a whole bunch of members [family physicians] who petitioned the AMA-- saying "we like this. This is great! Let's have more of this!" Well, the leaders of the AMA are politicians. And they're not complete idiots, they listen. And they finally heard what people were saying. (Physician T3)

It was only at the end of our study, where we observed alterations in AMA statements to reflect the new professional role identity of 'head of team', reframing the role identity of physicians as highly professional while sharing some responsibilities with other professionals.

As physicians find themselves treating an aging population and more patients with complex or chronic health conditions, it sometimes leaves them wondering how to find the time to care for their other patients. The answer, for a growing number of family physicians, is through a primary care network $(\mathrm{PCN}) \ldots$ The PCN creates a team environment by hiring other health professionals to assist physicians with some aspects of patient care. (Alberta Doctors' Digest, 2008:23)

Although the AMA had been initially reluctant to support a head of team professional role identity because of their focus on principles aligned with the professional logic, they eventually began to promote the implementation of standardized and multidisciplinary care as part of effective office management and quality care (market, state and professional logics).

What's really important is the attitude shift that appears to have happened within the Alberta Medical Association. .. a positive shift, I believe. ...they're seeing the value of what's happened in primary care reform and primary care change. And some of the naysayers are buying in. (Physician T3)

By 2009, the AMA pointed to the PCN as a successful model, arguing that doctors were able to provide better care by off-loading some of their work to other health professionals. By 2011 we observed evidence of acceptance of 'head of team': 
The concept of 'Patients First' seeks to provide improved patient wellness and optimal 'Value for Patients' by establishing the family physician as the leader of a team of health care professionals. (Alberta Doctors' Digest, 2011: 26)

In understanding how the new constellation of logics was re-embedded, we note that renegade physicians and managers successfully argued for increasing focus on standardized care as a route to improved patient outcomes, flow-through of patients, better clinic revenues and better physician lifestyles. Through private conversations, team meetings and eventual support from the AMA, physicians and other health professionals mutually reinforced the value of the new model. All of these changes were underpinned by physicians seeing themselves and the nature of their work as 'head of team' - with the new professional role identity guided by a strong (but reframed) professional logic, moderately strong market and state logics, and separated from the corporate logic.

Overall, we see that the four mechanisms facilitated the reinterpretation of relationships among logics, allowing physicians to see themselves in a new way - strong professionals who collaborate with others to provide high quality patient care. Reinterpreting the constellation of logics occurred through different types of interactions (some private and some more public) where professionals developed new patterns of cooperation and exchange.

\section{DISCUSSION}

We wanted to understand how collective professional role identity change could be accomplished in highly resilient settings where established practices and routines rely on mutual role expectations with multiple actors. Our data shows how institutional logics and the relationships among them were reinterpreted through different types of social interactions that shifted the collective professional role identity of physicians from "autonomous expert" to "head of team." We were struck by how this change required a tremendous amount of identity work on 
the part of a variety of people; managers and renegade physicians played a critical role by orchestrating particular opportunities for interaction in which "what it means to be a family physician" could be reconsidered. The resiliency of our setting meant that changing physicians' collective professional role identity took a metaphorical "village."

We found that a new professional identity for physicians was co-created though a collective process of reinterpreting the guiding institutional logics and the relationships among them that relied on four mechanisms: (1) Revealing the hidden influence of a logic, (2) Reinforcing the conflict between logics, (3) Reframing the meaning of a dominant logic, and (4) Re-embedding the new arrangement of logics. Figure 2 provides a schematic representation of how a new professional role identity can be co-created through a collective process of reinterpreting the guiding constellation of logics. Across the middle of the diagram, we situate the four mechanisms through which the focal profession (physicians in our case) and other actors reinterpreted the constellation of logics to facilitate professional role identity change. We also indicate the different types of interactions which were associated with each of these mechanisms. Above each of the mechanisms we indicate the changing nature of the constellation over time, and across the bottom of the diagram we show the changes in professional role identity and work practices.

[Figure 2 about here]

Our interviews across different locations showed similar progression through the four mechanisms, but of course some physicians moved towards a new professional role identity more quickly than others. Although we present the mechanisms sequentially, we note that there were varying degrees of overlap and back-tracking. The renegade physicians were anxious to engage in the new role, and very quickly incorporated new working relationships and a 'head of 
team' role identity to which they had aspired. Other physicians engaged with the new model more tentatively. However, by the end of our interviews, all physicians we interviewed told us about their positive view of the new role identity for physicians (what we have labeled 'head of team'), and explained how they saw themselves and their work in a new way.

Our study makes contributions to the literature on professional role identity and institutional logics. We contribute to the professional role identity literature by drawing on previous work regarding the relational aspect of identity (Sluss \& Ashforth, 2007) and the potential for individuals to regulate or condition the identity of others (Alvesson \& Willmott, 2002; Lok, 2010). We show that at the collective level there can be an important role for others in facilitating change in professional role identity for a focal group. Our focus is consistent with a social constructivist perspective (Berger \& Luckmann, 1967); however, our research pushes this conceptualization further by highlighting the purposeful actions of others whose goal of field level change relies on altering the professional role identity of a particular actor - in our case, family physicians. While the importance of interactions among field level actors has been acknowledged in previous studies of identity work (Langley et al., 2013; Pratt et al., 2006), there has been little sustained attention to the nature of such interactions. Our study highlights the agentic work of others in arranging interactions designed to convince professionals to first consider changing, and then to actually change their role identity over time.

In contrast to previous literature that suggests professional role identity change must be driven by professionals themselves (e.g. Chreim et al., 2007; Goodrick \& Reay, 2010), our study shows the potential for change to be orchestrated by others. We show that arguments developed by managers (with support from professional leaders and other co-workers) facilitated a process of reinterpreting the constellation of institutional logics guiding professional role identity. As a 
result, new meanings regarding the set of logics guiding professional role identity and work developed. While physicians were, of course, participants in the professional role identity change process, we observed that managers purposefully planned opportunities for interaction, engaging in strategically oriented meetings and conversations that set out a pathway toward a new physician role identity. Other professionals such as nurses and pharmacists also engaged with physicians to reinforce the value of teamwork. Thus, our study draws attention to a much stronger role for others in changing professional identity than has previously been considered.

Our second contribution is to increase attention on different types of social interactions and how they can alter the dynamics of changing professional role identity. Although Thornton et al. (2012) suggested that social interactions can mediate between institutional logics and the dynamics of professional role identities, there has been almost no empirical attention to how this occurs. We build on Berger and Luckmann (1967) who argue that it is through ongoing interactions and shared history that new collective meanings arise. Our focus on interactions also builds on recent suggestions that micro-level workplace interactions are important because they are the place where new meanings are developed and shared to shape organizational life (Fine \& Hallett, 2014; Gray et al., 2015). Similar to Kellogg's (2009) findings about the importance of the space within which interactions occur, we found that change in professional role identity relied on interactions that occurred in two different types of space - protected private space (e.g. one-on-one meetings) and more public space (e.g. group meetings). Interactions in private space can be more blunt and to-the-point than those where a larger audience is present; taboo subjects (such as financial compensation in our case) can be addressed. We suggest that interactions in such private spaces allow professionals some sense of safety in listening and responding to potentially challenging discussions such as we heard about with respect to physician payment 
plans. It is within the boundaries of a safe space that professionals may be able to reconsider the meaning of their professional selves and begin to see possibilities of change.

However, we suggest that interactions in more public or open space are also critical to developing a new professional role identity. We found that it was in group settings where relationships between physicians and others became evident to all. For example, when physician attendance at meetings clearly showed how physicians could be influenced by the market logic, it became possible for other professionals to take actions that facilitated further physician role identity change. That is, interactions in more public space led to increasing efforts among physicians and other professionals to co-create a new meaning of 'who physicians are.' This developing sense of a new professional role identity was therefore shared and created by physicians and those who worked with them in the same institutional context. In later stages of the change process, interactions in public spaces we also important for professionals to discuss accomplishments and develop a shared sense of pride to sustain the new role identity guided by a new constellation of logics.

Therefore, our study points to the importance of interactions occurring in both private and public space so that old meanings are challenged in relative safety, and new meanings can be contemplated and developed in both private and then public. Jenkins (1996) suggested that the concept of frontstage and backstage interactions (Goffman, 1969) is helpful in understanding individual self-image compared to public image. We push this idea to the level of professional role identity and suggest that behind the scene interactions may be critical to initial consideration of change and at particular junctures along the way. However public performances (at least with co-workers) may also be required to develop new professional role identities that can be sustained in an institutionalized context. We see that such workplace interactions allow 
professionals to reinterpret and rearrange the constellation of logics guiding professional role identity. This could happen in different ways in different settings, but in our case putting nurses into clinics and encouraging them to disrupt the established patterns by demonstrating new approaches led to new working arrangements among professionals and consequently the reconsideration of what it meant to be a 'good' physician. In other professionalized settings, work teams that require a new mix of professionals (such as architects and engineers working concurrently on specialized buildings) could facilitate similar reinterpretations of logics guiding professional practice and role identity.

Our third and final contribution is to the literature on institutional logics. By focusing on actors' (re)interpretations of constellations of logics, we take up Zilber's (2013) call to go beyond structure and give attention to the underlying meaning of logics. We contrast our work with previous theory concerning co-existing logics that focuses on the dominance of particular logics (Reay \& Hinings, 2009), or structural combinations of logics described as bricolage (Pache \& Santos, 2013); instead, we suggest that in addition to these structural arrangements, it is critical to consider actors' interpretations (McPherson \& Sauder, 2013) and reinterpretations of multiple logics and the relationships among them. Drawing on Swidler's (1986) concept of a toolkit and her suggestion that some tools may be known to people even though they are not selfevident in use, our study shows how the meaning of a hidden logic (the market logic in our case) can influence behavior. When others reveal the importance of previously hidden logics, actors have the opportunity to reconsider their seemingly entrenched behavior and develop new meanings that can support a reinterpretation of the constellation of logics. As we noted above, this process of 'revealing' likely requires safe and protected space (private meetings in our case) where old meanings can be challenged and reconsidered without fear of reputational damage. We 
suggest that further consideration of hidden logics in other research setting could provide important new insights about institutional change or resilience.

We also show how different interpretations of institutional logics by different actors led to a reconfiguring of the constellation of logics and a new meaning of professionalism in support of a new role identity. Our work extends that of Currie and Spyridonidis (2015) who suggested that actors could collectively renegotiate the guiding constellation of logics on behalf of others to facilitate practice change. Our micro-level research illuminates how the constellation of logics can be reinterpreted to support change, as opposed to simply establishing that the reinterpretation of logics occurred. Moreover, our focus on the importance of physical space to the reinterpretation of institutional logics further explicates how the location of social interaction matters (Smets et al., 2015). As such, we add to a developing literature that emphasizes how actors "on the ground" interpret logics and use them in their everyday work (McPherson \& Sauder, 2013) as well as how the relationships among logics are socially constructed (Smets \& Jarzabkowski, 2013). While Smets and Jarzabkowski (2013) showed how actors can reinterpret the relationship between two logics so that both are viewed as relevant to a particular domain, and McPherson and Sauder (2013) showed how multiple logics are reinterpreted to guide action, we show how multiple logics and their relationships can be reinterpreted to support a new professional role identity.

Overall, we suggest that an understanding of professional role identity change is incomplete unless we take into account the institutional context. Particularly in highly institutionalized contexts where there are multiple mechanisms to reinforce the stability of the system (Pratt et al., 2006), collective professional role identity change is likely to require the purposeful involvement of actors who destabilize the system by altering the interpretation and 
relationships among potentially competing logics. We see this as an important advancement because it brings new sources of agency to light.

\section{CONCLUSIONS}

In this paper, we show how collective professional role identity was changed through a process of reinterpreting multiple logics and their relationships through the interactions of multiple actors. Our study shows the important role that others played in encouraging the reinterpretation and reconfiguration of co-existing logics supporting a new professional role identity for physicians. Managers were purposeful and focused as they facilitated different types of interactions designed to gradually shift the meanings associated with professionalism; however, we certainly recognize that physicians had to be willing participants in the change process, and that the provincial medical association had to eventually acquiesce. Overall, we see that it was through a combination of private and more open social interactions that the guiding constellation of logics was reinterpreted allowing physicians to see themselves differently - as an informed head of the team, rather than an autonomous expert.

While the processes for professional role identity change we observed may be generalizable to role identity change in a variety of contexts, we believe that our findings are particularly relevant for highly institutionalized settings where well-established and taken for granted patterns of behavior, values, and beliefs can lead to such extreme resiliency that change becomes virtually impossible. Professionals in particular are well known for perpetuating the status quo. Thus, it is important to note the significance of the change in collective professional role identity we observed: the shift in role identity opened up new approaches to providing primary health care associated with higher quality care and increased access for patients. 
The nature of our investigation means that we were able to collect in-depth data from multiple actors and documents produced over time. Because of this longitudinal research approach, we were well positioned to focus on how a new collective professional role identity was developed. Unlike proverbial leopards that cannnot change their spots, our study suggests that professional role identity can change through the collective actions of a number of actors (including the leopard) reinterpreting and reconstructing relationships among multiple coexisting logics.

\section{REFERENCES}

Alberta Doctors Digest. 2011. Patients First: AMA vision for primary and chronic care. January/February: 25-27.

Alberta Doctors Digest. 2010. Minister's committee recommends new framework on health. May/June: 16-19.

Alberta Doctors Digest. 2008. All for one: PCNs bring collaborative approach to patient care. January/February: 23-25.

Alberta Doctors Digest. 2005. Alternate relationship plans: New principles and procedures. January/ February: 9-10.

Alberta Medical Association. 2010. Physician Fact Sheet.

Abbott, A. 1988. The System of Professions: An Essay on the Division of Expert Labor. Chicago: The University of Chicago Press.

Alvesson, M. \& Willmott, H. 2002. Producing the appropriate individual: Identity regulation as organizational control. Journal of Management Studies, 39: 619-644.

Barbour, J. B., \& Lammers, J. C. 2015. Measuring professional identity: A Review of the literature and a multilevel confirmatory factor analysis of professional identity constructs. Journal of Professions and Organizations, 2, 38-60.

Barley, S. R. 1989. Careers, identities, and institutions: The legacy of the Chicago School of Sociology. In M. B. Arthur, D. T. Hall, \& B. S. Lawrence (Eds.), Handbook of Career Theory: 41-65. Cambridge: Cambridge University Press.

Becker, H.S., Geer, B., Hughes, E.C. \& Strauss, A.L. 1961. Boys in White: Student Culture in Medical School. Chicago: University of Chicago Press.

Berger, P. L. \& Luckmann, T. 1967. The Social Construction of Reality: A Treatise in the Sociology of Knowledge. Garden City, NY: Anchor Books.

Binder, A. 2007. For love and money: Organizations' creative responses to multiple environment logics. Theory and Society, 36(6): 547-571.

Brown, A. D. 2015. Identities and identity work in organizations. International Journal of Management Reviews, 17(1), 20-40. 
Brown, A.D. \& Lewis, M.A. 2011. Identities, Discipline and Routines. Organization Studies, 32(7): 871-895.

Casebeer, A. \& Reay, T. 2012. Taking the Gaps Seriously: The Experience of Primary Health Care Networks in Western Canada. In Dickinson, H. \& Mannion, R. (Eds.), The reform of health care: shaping, adapting and resisting policy developments

Chreim, S., Williams, B.E., \& Hinings, C.R. 2007. Inter-level influences on the reconstruction of professional role identity. Academy of Management Journal, 50: 1515-1539.

Corley, K.G. \& Gioia, D.A. 2004. Identity ambiguity and change in the wake of a corporate spinoff. Administrative Science Quarterly 49(2): 173-208.

Cresswell, J.W. 2013. Qualitative Inquiry \& Research Design. Los Angeles: Sage.

Currie, G., Lockett, A., Finn, R., Martin, \& G., Waring, J. 2012. Institutional work to maintain professional power: Re-creating the model of medical professionalism Organization Studies, 33: 937-962.

Currie, G. \& Spyridonidis, D. 2016. Interpretation of multiple institutional logics on the ground: Actors' position, their agency and situational constraints in professionalized contexts. Organization Studies, 37(1): 77-97.

Edmondson, A. C., Bohmer, R \& Pisano, G.P. 2001. Disrupted Routines: Team Learning and New Technology Adaptation. Administrative Science Quarterly, 46: 685-716.

Fine, G.A. \& Hallett, T. 2014. Group cultures and the everyday life of organizations: Interaction orders and meso-analysis. Organization Studies, 35(12): 1773-1792.

Freidson, E. 2001. Professionalism: The Third Logic. London: Polity Press.

Friedland, R., \& Alford, R.R. 1991. Bringing society back in: Symbols, practices, and institutional contradictions. In W. W. Powell, \& P. J. DiMaggio (Eds.), The new institutionalism in organizational analysis: 232-263. Chicago: University of Chicago Press.

Glaser, B.G. \& Strauss, A.L. 1967. The Discovery of Grounded Theory: Strategies for Qualitative Research. Hawthorne, NY: Aldine de Gruyter.

Golden-Biddle, K. \& Locke, K. 2007. Composing Qualitative Research. Thousand Oaks: Sage.

Goodrick, E., \& Reay, T. 2010. Florence Nightingale Endures: Legitimizing a New Professional Role Identity. Journal of Management Studies, 47(1): 55-84.

Goodrick, E. \& Reay, T. 2011. Constellations of Institutional Logics: Changes in the professional work of pharmacists. Work and Occupations, 38(3): 372-416.

Gray, B., Purdy, J.M. \& Ansari, S. 2015. From interactions to institutions: Microprocesses of framing and mechanisms for the structuring of institutional fields. Academy of Management Review, 40(1): 115-143.

Goffman, E. 1969. The presentation of self in everyday life. London: Allen Lane.

Greenwood, R., Raynard, M., Kodeih, F., Micelotta, E.R., \& Lounsbury, M. 2011. Institutional complexity and organizational responses. The Academy of Management Annals, 5: 317371.

Ibarra, H. 1999. Provisional selves: Experimenting with image and identity in professional adaptation. Administrative Science Quarterly, 44(4) 764-791.

Jenkins, R. 1996. Social Identity. London: Routledge.

Kellogg, K.C. 2009. Operating room: Relational spaces and microinstitutional change in surgery. American Journal of Sociology, 115(3): 657-711.

Langley, A. 1999. Strategies for theorizing from process data. Academy of Management Review, 24: 691-710. 
Langley, A., Golden-Biddle, K., Reay, T., Denis, J-L., Hébert, Y., Lamothe, L, Gervais, J. 2013. Identity struggles in merging organizations: Renegotiating the sameness-difference dialectic. Journal of Applied Behavioral Science, 48(2): 135-167.

Locke, K.D. 2003. Grounded Theory in Management Research. London: Sage.

Lok, J. 2010. Institutional logics as identity projects. Academy of Management Journal, 53: $1305-1335$.

McPherson, C. \& Sauder, M. 2013. Logics in Action: Managing Institutional Complexity in a Drug Court. Administrative Science Quarterly, 58(2): 165-196.

Meyer, R.E. \& Hammerschmid, G. 2006. Changing institutional logics and executive identities. A managerial challenge to Public Administration in Austria. American Behavioral Scientist, 49(7): 1000-1014.

Myers, M.D. 2013. Qualitative Research in Business \& Management. London: Sage.

Nelson, A.J. \& Irwin, J. 2014. "Defining what we do - all over again": Occupational identity, technology change, and the librarian/ internet-search relationship. Academy of Management Journal, 57(3): 892-928.

Pache, A.C. \& Santos, F. 2013. Inside the hybrid organization: Selective coupling as a response to conflicting institutional logics. Academy of Management Journal, 56(4): 972-1001.

Poole, M.S. 2004. Central issues in the study of change and innovation. In M.S. Poole. \& A.H. Van de Ven (Eds.), Handbook of Organizational Change and Innovation: 3-31. Oxford: Oxford University Press.

Pouthier, V., Steele, C.W.J. \& Ocasio, W. 2013. From agents to principles: The changing relationship between hospitalist identity and logics of health care. In M. Lounsbury \& E. Boxenbaum (Eds.) Institutional Logics in Action, Part A (Research in the Sociology of Organizations, Volume 39): 203-241. Emerald Group Publishing Limited.

Powell, W.W. \& DiMaggio, P. 1991. Introduction. In W.W. Powell \& P. DiMaggio (Eds.), The New Institutionalism in Organizational Analysis: 1-38. Chicago, IL: University of Chicago Press.

Pratt, M.G., Rockmann, K.W., \& Kaufmann, J. B. 2006. Constructing professional identity: The role of work and identity learning cycles in the customization of identity among medical residents. Academy of Management Journal, 49: 235-262.

Rao, H., Monin, P., \& Durand, R. 2003. Institutional change in Toque Ville: Nouvelle Cuisine as an identity movement in French gastronomy. American Journal of Sociology, 108: 795-843.

Reay, T., GermAnn, K., Casebeer, A., Golden-Biddle, K. \& Hinings, C.R. (Bob). Forthcoming. Creating and Sustaining the Right Kind of Space for Organizational Learning in Primary Healthcare. In Swan, J., Nicolini, D. \& Newell, S. (Eds), Mobilizing Knowledge in Healthcare. Oxford University Press.

Reay, R, Golden-Biddle, K. \& GermAnn, K. 2016. Legitimizing a new role: Small wins and microprocesses of change. Academy of Management Journal, 49(5): 977-998.

Reay, T., Goodrick, E., Casebeer, A. \& Hinings, C.R. 2013. Legitimizing New Practices in Primary Health Care. Health Care Management Review. 38(1):9-19.

Reay, T. \& Hinings, C.R. 2005. The Recomposition of an Organizational Field: Health care in Alberta. Organization Studies, 26 (3): 351-384.

Reay, T \& Hinings, C.R. 2009. Managing the Rivalry of Competing Institutional Logics. Organization Studies, 30 (06): 629-652. 
Schwalbe, M. L., \& Mason-Schrock, D. (1996). Identity work as group process. Advances in group processes, 13(113), 47.

Scott, W.R. 2014. Institutions and Organizations, $4^{\text {th }}$ edition. Thousand Oaks: Sage.

Scott, W.R. 2008. Lords of the Dance: Professionals as Institutional Agents. Organization Studies, 29 (2): 219-238.

Sluss, D. M., \& Ashforth, B. E. 2007. Relational identity and identification: Defining ourselves through work relationships. Academy of Management Review, 32(1), 9-32.

Smets, M. \& Jarzabkowski, P. 2013. Reconstructing institutional complexity in practice: A relational model of institutional work and complexity. Human Relations, 1-31.

Smets M., Jarzabkowski, P., Burke, G. \& Spee, P. (2015) Reinsurance trading in Lloyd's of London: Balancing conflicting-yet-complementary logics in practice. Academy of Management Journal, 58(3), 932-970.

Snow, D.A. \& Anderson, L. 1987. Identity work among the homeless: The verbal construction and avowal of personal identities. American Journal of Sociology, 92:1336-1371.

Stake, R.E. 1995. The Art of Case Study Research. Thousand Oaks: Sage.

Stryker, S. \& Serpe, R.T.1982. Commitment, Identity Salience, and Role Behavior: A Theory and Research Example. In W. Ickes \& E.S. Knowles (Eds.), Personality, Roles, and Social Behavior: 199-218. New York: Springer Verlag.

Stryker, S. 2007. Identity Theory and Personality Theory: Mutual Relevance. Journal of Personality, 75: 1083-1102.

Stryker, S. \& Statham, A. 1985. Symbolic Interaction and Role Theory. In G. Lindzey \& E. Aronson (Eds.), Handbook of Social Psychology: 311-78. New York: Random House.

Sveningsson, S. \& Alvesson, M. 2003. Managing managerial identities: Organizational fragmentation, discourse and identity struggle. Human Relations, 56: 1163-1193.

Swidler, A. 1986. Culture in action: symbols and strategies. American Sociological Review, 51, 273-286.

Thornton, P.H., Ocasio, W., \& Lounsbury, M. 2012. The Institutional logics perspective: A new approach to culture, structure, and process. Oxford: Oxford University Press.

Thornton, P.H. \& Ocasio, W. 2008. Institutional Logics. In R. Greenwood, C. Oliver, K. Sahlin \& R. Suddaby (Eds.), Handbook of Organizational Institutionalism: 99-129. CA: Sage.

Townley, B. 1997: The Institutional Logic of Performance Appraisal. Organization Studies, 18 (2), 261-285.

Vough, H., Bednar, J., Cardador, T., Dane, E. \& Pratt, M.G. 2013. What Clients Don't Get about my Profession: A Model of Perceived Role-Based Image Discrepancies. Academy of Management Journal, 56(4): 1050-1080.

Waldorff, S.B., Reay, T. \& Goodrick, E. 2013. A tale of two countries: How different constellations of logics impact action. In M. Lounsbury \& E. Boxenbaum (Eds.), Institutional Logics in Action, Part A (Research in the Sociology of Organizations, Volume 39): .99-129. Emerald Group Publishing Limited.

Zilber, T. B. 2013. Institutional Logics and Institutional Work: Should They Be Agreed? In M. Lounsbury \& E. Boxenbaum (Eds.), Institutional Logics in Action, Part A (Research in the Sociology of Organizations, Volume 39): 77-96. Emerald Group Publishing Limited. 
Table 1: Data Sources

\begin{tabular}{|c|c|c|c|c|c|c|}
\hline YEAR & \multicolumn{3}{|c|}{ INTERVIEW DATA } & \multicolumn{3}{|c|}{ ARCHIVAL DATA } \\
\hline & Source & \# interviews & \# pages & Source & \# documents & \# pages \\
\hline \multirow[t]{3}{*}{2004} & & & & Government & 10 & 50 \\
\hline & & & & AMA & 2 & 4 \\
\hline & & & & Newspaper & 7 & 7 \\
\hline \multirow[t]{3}{*}{2005} & Physicians & 5 & 130 & Government & 9 & 45 \\
\hline & Managers & 7 & 182 & AMA & 5 & 10 \\
\hline & & & & Newspaper & 20 & 20 \\
\hline \multirow[t]{3}{*}{2006} & Physicians & 20 & 520 & Government & 10 & 50 \\
\hline & Managers & 22 & 572 & AMA & 4 & 8 \\
\hline & Other profs. & 10 & 260 & Newspaper & 19 & 19 \\
\hline \multirow[t]{3}{*}{2007} & Physicians & 21 & 546 & Government & 10 & 50 \\
\hline & Managers & 22 & 572 & AMA & 7 & 14 \\
\hline & Other profs. & 7 & 182 & Newspaper & 23 & 23 \\
\hline \multirow[t]{3}{*}{2008} & Physicians & 17 & 442 & Government & 10 & 50 \\
\hline & Managers & 22 & 572 & AMA & 6 & 12 \\
\hline & Other profs. & 9 & 234 & Newspaper & 34 & 34 \\
\hline \multirow[t]{3}{*}{2009} & & & & Government & 2 & 10 \\
\hline & & & & AMA & 7 & 14 \\
\hline & & & & Newspaper & 23 & 23 \\
\hline \multirow[t]{3}{*}{2010} & & & & Government & 4 & 20 \\
\hline & & & & AMA & 9 & 18 \\
\hline & & & & Newspaper & 28 & 28 \\
\hline \multirow[t]{3}{*}{2011} & & & & Government & 4 & 20 \\
\hline & & & & AMA & 8 & 16 \\
\hline & & & & Newspaper & 24 & 24 \\
\hline \multirow[t]{3}{*}{2012} & & & & Government & 4 & 20 \\
\hline & & & & AMA & 9 & 18 \\
\hline & & & & Newspaper & 36 & 36 \\
\hline Totals & & 162 & 4,212 & & & 643 \\
\hline
\end{tabular}


Table 2: Institutional Logics, Key Aspects and Associated Ideal Type Professional Role Identity

\begin{tabular}{|c|c|c|}
\hline $\begin{array}{c}\text { Institutional } \\
\text { Logic }\end{array}$ & Key Aspects of Ideal Type & $\begin{array}{l}\text { Ideal Type Professional Role } \\
\text { Identity } \\
\text { ("Who are we and how do we do } \\
\text { our work?") - if guided by single } \\
\text { ideal type institutional logic }\end{array}$ \\
\hline Professional & $\begin{array}{ll}\text { - } & \text { Expert Knowledge } \\
\text { - } & \text { Autonomous decision- } \\
& \text { making } \\
\text { - } & \text { Recognized Status \& } \\
& \text { Responsibility } \\
\text { - } & \text { Quality controlled by } \\
& \text { service provider }\end{array}$ & $\begin{array}{l}\text { Physicians see selves as experts who } \\
\text { hold unique knowledge } \\
\& \text { make decisions about patient } \\
\text { treatment based on their evaluation of } \\
\text { patient need. }\end{array}$ \\
\hline Market & $\begin{array}{l}\text { - 'Supply \& demand' } \\
\text { determines nature and } \\
\text { price of service } \\
\text { - "Buyer Beware" } \\
\text { - } \text { Quality determined by } \\
\text { consumer demand }\end{array}$ & $\begin{array}{l}\text { Physicians see selves as holding a rare/ } \\
\text { unique resource (knowledge) } \\
\& \text { make decisions based on how to } \\
\text { gain greatest financial returns. }\end{array}$ \\
\hline Corporate & 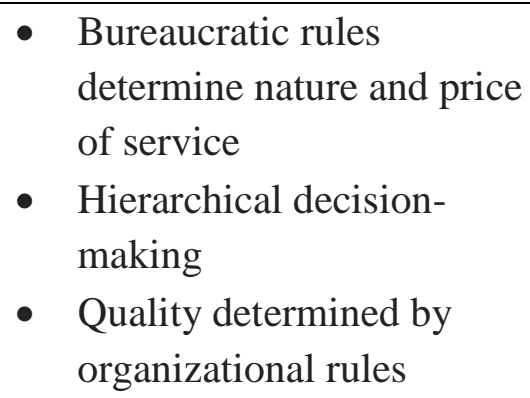 & $\begin{array}{l}\text { Physicians see selves as holding } \\
\text { positions of authority within an } \\
\text { organization } \\
\& \text { make decisions about patient } \\
\text { treatment by following established } \\
\text { organizational rules. }\end{array}$ \\
\hline State & $\begin{array}{l}\text { - Legislation determines } \\
\text { nature and price of service } \\
\text { - Equal access for all } \\
\text { citizens } \\
\text { - Quality determined by } \\
\text { legislation }\end{array}$ & $\begin{array}{l}\text { Physicians see selves as government } \\
\text { representative with responsibilities to } \\
\text { provide services for all, thus } \\
\text { improving population health } \\
\text { \& make decisions based on best } \\
\text { outcomes for population health. }\end{array}$ \\
\hline
\end{tabular}


Table 3: Additional quotes

\begin{tabular}{|c|c|}
\hline $\begin{array}{l}\text { Indicators of Change in } \\
\text { Professional Role Identity } \\
\text { and Work Practices }\end{array}$ & $\begin{array}{l}\text { [This new arrangement] has taken people, including physicians, from being isolated } \\
\text { and working independently, to working now collaboratively, to seeing the value of } \\
\text { each other, to enjoying the value of each other. (Manager T3) } \\
\text { In the beginning it was like starting off and people all thought that nothing was } \\
\text { going to happen and there wasn't going to be any funding. And it was very hard to } \\
\text { actually keep on going because there was so much negativity. And it was a really } \\
\text { gratifying thing to see now that the majority of physicians are actually participating } \\
\text { and sending their patients. [They are] just generally now very engaged in } \\
\text { comparison to the start. [They are actually doing things differently] on a daily basis. } \\
\text { So to me that's quite a big change. And I think they're happy to be part of the PCN. } \\
\text { (Physician T3) }\end{array}$ \\
\hline \multicolumn{2}{|c|}{ Mechanism: Revealing the Influence of a Hidden Logic } \\
\hline $\begin{array}{l}\text { a. Showing effect of } \\
\text { financial incentives on } \\
\text { physician behavior }\end{array}$ & $\begin{array}{l}\text { [I explained the approach by telling the physicians] your access to the lion's share of } \\
\text { [the money] will be based on the overall performance. And there's docs that } \\
\text { populate these governance positions, and you'll be rewarded for taking a leadership } \\
\text { role in the network. (Manager T0) }\end{array}$ \\
\hline $\begin{array}{l}\text { b. Convincing physicians } \\
\text { that financial } \\
\text { incentives are } \\
\text { important to improving } \\
\text { patient care }\end{array}$ & $\begin{array}{l}\text { I call up physicians and I say, "Have I got a deal for you" and I use shame and guilt. I say, } \\
\text { "You know, you really should participate - you're in this PCN and so you need to take } \\
\text { advantage of this and just try it. Just promise me you'll try it. So out of self-defense and } \\
\text { to get me off the phone they try it. 'Cause I believe that they will see the benefits to it and } \\
\text { that certainly has happened. (Manager T1) } \\
\text { We're learning about the value to the whole system of having an efficient office practice. } \\
\text { We're working on improving access to physicians by changing the system within the way } \\
\text { we run the clinic. The health region managers are leading this.. [they] saw the potential } \\
\text { and the power of these programs and how it could help us, and they tapped into it. } \\
\text { (Physician T1) }\end{array}$ \\
\hline \multicolumn{2}{|c|}{ Mechanism: Reinforcing the Conflict between Logics } \\
\hline $\begin{array}{ll}\text { a. } & \text { Protecting } \\
& \text { physicians from }\end{array}$ & $\begin{array}{l}\text { [We were told we had to have] a letter of intent. And [the Regional managers] said, we } \\
\text { know that you guys are struggling. You're all practicing doctors. You don't know how to } \\
\text { write letters of intent. We'll help you. (Physician T1) }\end{array}$ \\
\hline
\end{tabular}




\begin{tabular}{|c|c|}
\hline administrative work & $\begin{array}{l}\text { We showed physicians our value by taking on what we call 'business development.' We } \\
\text { look at their leases and negotiate on their behalf. We've also taken on the responsibility } \\
\text { for making sure physicians get paid [from the government] in a timely fashion. (Manager } \\
\text { T2) }\end{array}$ \\
\hline $\begin{array}{l}\text { b. Distinguishing } \\
\text { physicians as too } \\
\text { valuable for } \\
\text { administrative work }\end{array}$ & $\begin{array}{l}\text { Well, I think we really benefit from more help with the administrative side. When a group } \\
\text { of physicians has someone else dedicated to looking after the paperwork, we have time } \\
\text { for patients .. it's a better environment so that the team is actually working together } \\
\text { (Physician T2). } \\
\text { We've been hiring quite a few people [for the team]. Thankfully [the manager] has been } \\
\text { doing this work. We physicians certainly don't want to do the hiring... We're the only } \\
\text { ones that can do physician work. (Physician T1) }\end{array}$ \\
\hline \multicolumn{2}{|c|}{ Mechanism: Reframing the Meaning of a Dominant Logic } \\
\hline $\begin{array}{l}\text { a. Expounding the } \\
\text { importance of } \\
\text { physician expertise }\end{array}$ & $\begin{array}{l}\text { There were complex patients who, in the physicians' own words - they had bits of care } \\
\text { that were left undone. So we said, ok, we're going to help in the complex care. You } \\
\text { [physicians] do your part that others can't do, and then we'll support [with other } \\
\text { professionals]. (Manager T2) } \\
\text { We've got nurses in our physician's offices. They've gained [our] trust and respect. } \\
\text { We're now in the team building process, giving nurses more skills and more tools to start } \\
\text { to manage patients a little more independently than they do now... It all helps us do the } \\
\text { most important things that only doctors can do. (Physician T2) }\end{array}$ \\
\hline $\begin{array}{ll}\text { b. } & \text { Redefining } \\
\text { physician control as } \\
\text { being informed }\end{array}$ & $\begin{array}{l}\text { They'll [patients] come to the [diabetes] program. They will get whichever modules that } \\
\text { are deemed appropriate. We get information faxed back to us because that's the system } \\
\text { that works at this point in time saying they've attended the program or whatever. Patients } \\
\text { get better care and we [physicians] stay informed. (Physician T3) } \\
\text { We finally got nurses into the physician offices, and we encouraged them [nurses] to } \\
\text { figure out ways to be helpful. .. And for the most part it's gone quite well. We've now } \\
\text { had a really good response from the physicians saying that they're absolutely happy with } \\
\text { the nurses and they can't imagine life now without them. (Manager T2) }\end{array}$ \\
\hline
\end{tabular}




\begin{tabular}{|c|c|}
\hline $\begin{array}{l}\text { c. } \text { Constructing } \\
\text { professionalism as } \\
\text { holding } \\
\text { responsibility for } \\
\text { population health }\end{array}$ & $\begin{array}{l}\text { Basically, we're getting more support in the area of chronic disease care. Getting various } \\
\text { drug formulary decisions made for patient care. And looking after dietary things for the } \\
\text { patient. They have now expert advice in those areas. And it's readily available. And it } \\
\text { reduces the amount of work that the physician has to do in those areas. And I think } \\
\text { improves patient care at the same time. So...It's a huge change. (Physician T3) } \\
\text {...while we work with the multidisciplinary team members, we can find different issues } \\
\text { that are actually causing blockages to having [patients] improve their health. So we can } \\
\text { have one staff member talking with them about a particular issue, and then I might talk to } \\
\text { them, and the nurse might talk to them, and the pharmacist. And we each have a little bit } \\
\text { of a different way of approaching the problem. And that can help us with overall health. } \\
\text { (Physician T3) }\end{array}$ \\
\hline \multicolumn{2}{|c|}{ Mechanism: Re-embedding New Arrangement of Logics } \\
\hline $\begin{array}{ll}\text { a. } & \text { Focusing on } \\
\text { evidence-based } \\
\text { protocols and } \\
\text { guidelines } \\
\text { associated with } \\
\text { standardized care }\end{array}$ & $\begin{array}{l}\text { I remember that the first time we were able to demonstrate the improvement for patients, } \\
\text { the physicians got excited. We had a meeting and gave a presentation to the team, and we } \\
\text { showed [for diabetics] significant improvement in hemoglobin A1Cs, compliance with } \\
\text { eye and foot exams, and huge patient satisfaction in surveys we had done. The reaction } \\
\text { was great -- everyone, particularly physicians said, 'Great!' (Manager T3) }\end{array}$ \\
\hline $\begin{array}{ll}\text { b. } & \text { Linking } \\
& \text { multidisciplinary } \\
\text { teamwork with } \\
\text { increased patient } \\
\text { numbers and clinic } \\
\text { revenues }\end{array}$ & $\begin{array}{l}\text { It's been acknowledged by the physicians, by the other healthcare providers that are } \\
\text { working alongside, and by the patients. This really is working much better from their } \\
\text { perspective. From a physician standpoint it's a way to meet the demands of not only their } \\
\text { existing population but as the population grows... And it doesn't hurt that clinic revenues } \\
\text { have gone up too. (Manager T3) } \\
\text { And it's just incredible, and I can say this as one of the docs, we're far tighter in control, } \\
\text { there's much less risk to patients I believe. It's just a far better way to practice medicine. } \\
\text { Really it's what I might generically call a better way of providing primary care... I think } \\
\text { they're [patients] getting good care, and our clinic is more sustainable. (Physician T3) }\end{array}$ \\
\hline
\end{tabular}


Figure 1: Coding Categories and Mechanisms

\begin{tabular}{|l|l|l|}
\hline \multicolumn{1}{|c|}{$1^{\mathrm{ST}}$ ORDER CODES } & \multicolumn{1}{|c|}{$2^{\mathrm{ND}}$ ORDER CODES } \\
\hline \begin{tabular}{l|l|} 
- Physicians attend meetings \\
- Managers encourage talking out \\
loud about financial incentives \\
- Managers argue importance of \\
incentives for physicians
\end{tabular} & $\begin{array}{l}\text { Showing effect of financial incentives } \\
\text { on physician behavior through one- } \\
\text { on-one conversations \& group } \\
\text { meetings }\end{array}$ \\
\hline $\begin{array}{l}\text { - Managers connect physician } \\
\text { incentives with better decision-making } \\
\text { - Nurses adapt work routines to fit } \\
\text { with physician financial incentives }\end{array}$ & $\begin{array}{l}\text { Convincing physicians that financial } \\
\text { incentives were important to } \\
\text { improving patient care through one- } \\
\text { on-one conversations \& group } \\
\text { meetings }\end{array}$ \\
\hline
\end{tabular}

- Physicians voice their dislike of administrative work

- Managers offer to take over administrative work

- AMA reps want physicians to focus on professional responsibilities - Managers say physicians can be 'better' professionals by doing physician work

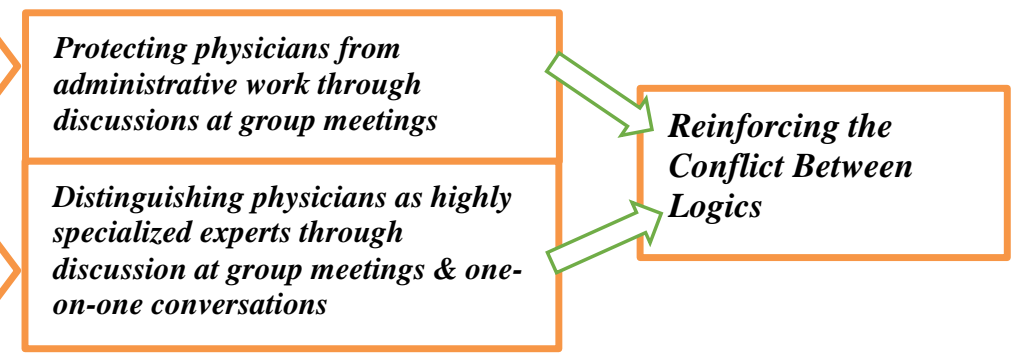

- Physicians agree that other professionals can take on new tasks - Managers promote special expertise of physicians

- Physicians and other professionals develop new work routines together - Other professionals ensure physicians are kept informed

- Managers \& renegade physicians justify PCN as way to increase patient access and maintain quality of care

- Physicians see increased patient access as positive indicator

- Managers celebrate improved patient outcomes at team meetings

- Physicians view standardized care as positive team accomplishment

- Physicians equate success with increased patients \& clinic revenues - Managers promote success of physicians gaining control over time

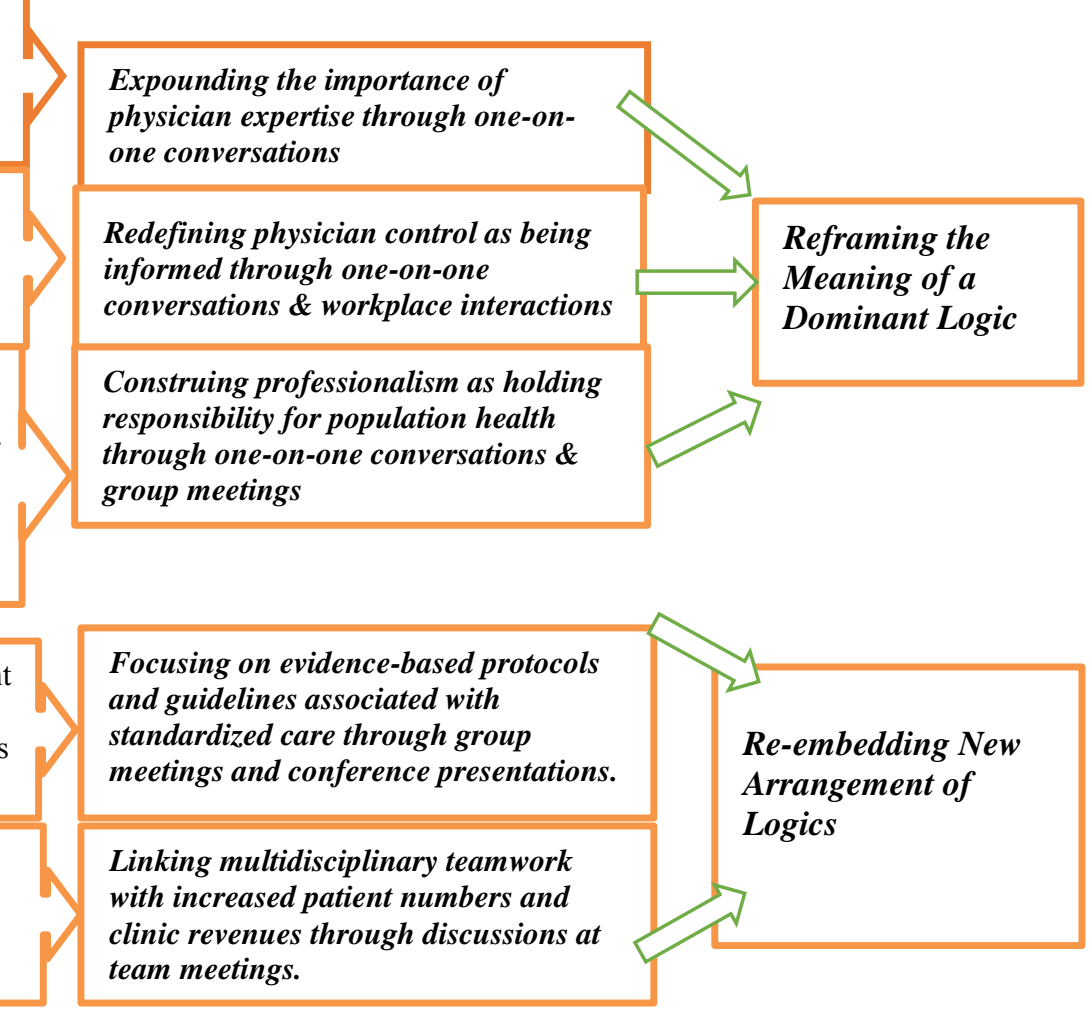


Figure 2: Co-creating a New Professional Role Identity by Re-interpreting Institutional Logics through Social Interactions
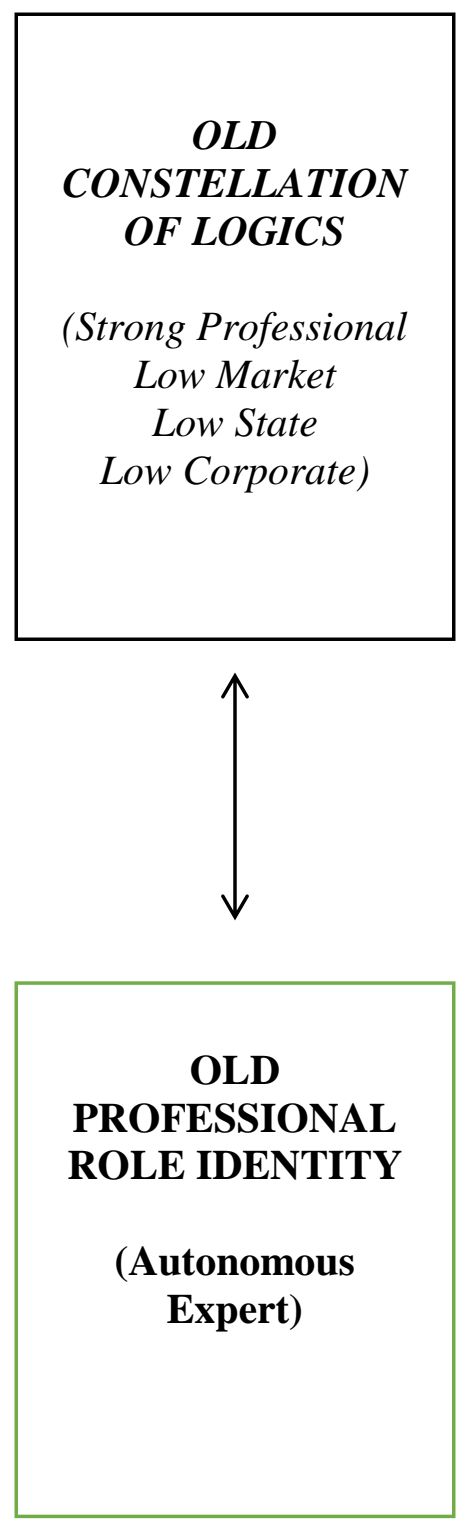
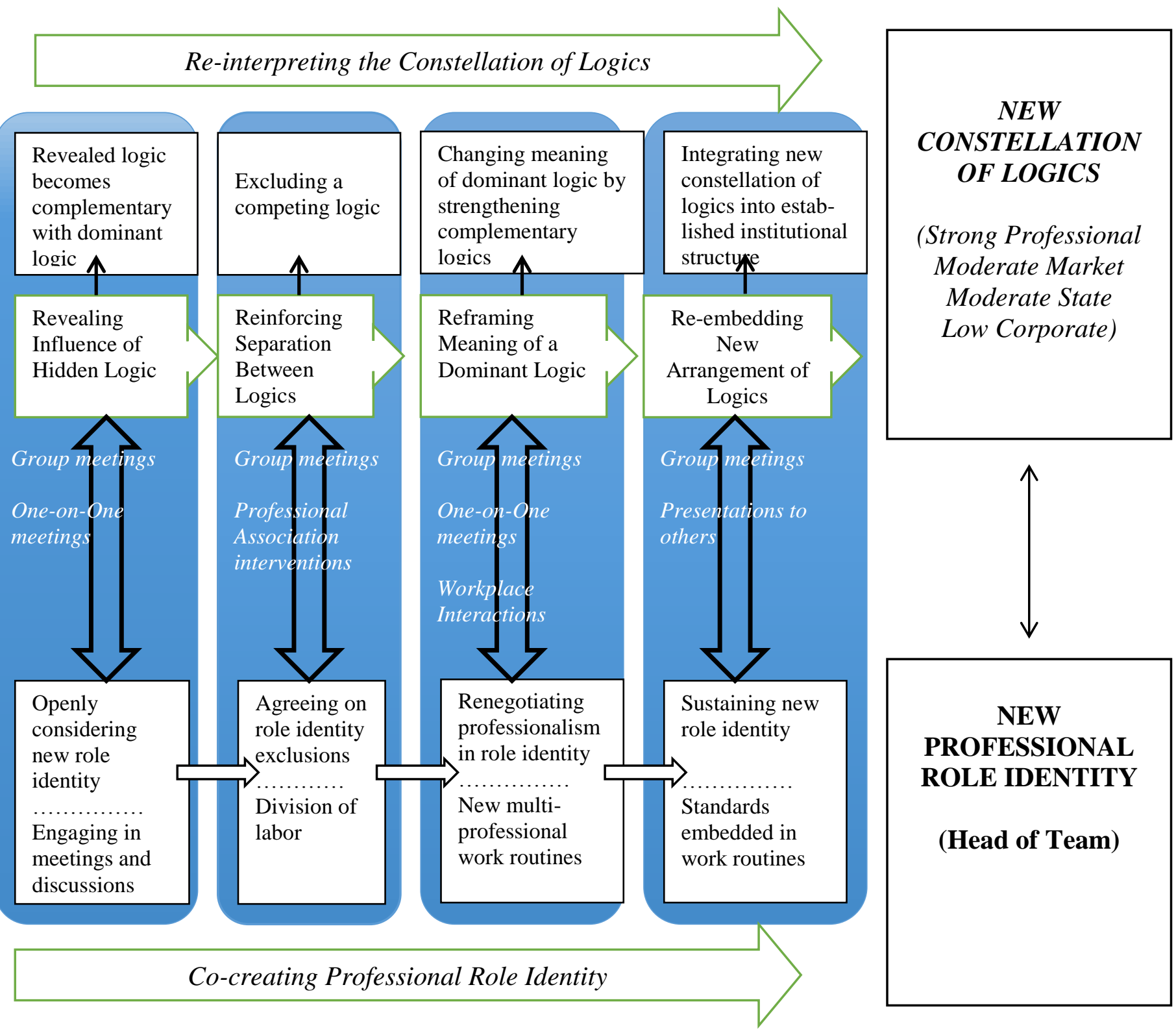


\section{AUTHOR BIOGRAPHICAL SKETCHES}

Trish Reay (trish.reay@ualberta.ca) is associate professor at the University of Alberta School of Business. She received her PhD in organizational analysis from the University of Alberta, Canada. Her research interests include institutional and organizational change, professions and professional identity. She has investigated these topics in the context of health care and family business.

Elizabeth Goodrick (goodrick@ fau.edu) is associate professor in the Health Administration Program at the Florida Atlantic University College of Business, USA. She received her PhD in Organizational Behavior and Theory from the University of Illinois at Urbana-Champaign. She studies health care professionals and organizations from a neo institutional perspective.

Susanne Boch Waldorff (sbw.ioa@cbs.dk) is associate professor at Copenhagen Business School, where she is also the director for Center for Health Management. She received her PhD in organizational analysis from Copenhagen School of Business. Her research interests include translations of reform and policy into organizational practices, public sector management, innovation, and professions.

Ann Casebeer (a.casebeer@ucalgary.ca) is adjunct Professor in the Department of Community Health Sciences, University of Calgary, Canada. She received her PhD from the University of Calgary. Her research has targeted mechanisms advancing change for health gain including: developing experiential learning platforms; broadening the stakeholder base for health system decision making; and, evaluating team and networked based innovation. 